Discussion Paper No. 17-034

\title{
The Development of Corporate
}

Tax Structures in the European Union from 1998 to 2015 -

\section{Qualitative and Quantitative Analysis}

Rainer Bräutigam, Christoph Spengel, and Kathrin Stutzenberger

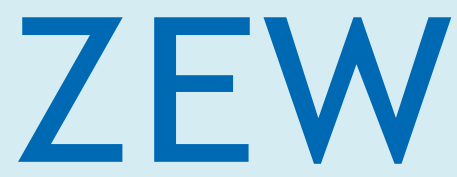

Zentrum für Europäische Wirtschaftsforschung $\mathrm{GmbH}$

Centre for European

Economic Research 


\title{
Discussion Paper No. 17-034 \\ The Development of Corporate Tax Structures in the European Union from 1998 to 2015 - Qualitative and Quantitative Analysis
}

\author{
Rainer Bräutigam, Christoph Spengel, \\ and Kathrin Stutzenberger
}

Download this ZEW Discussion Paper from our ftp server:

http://ftp.zew.de/pub/zew-docs/dp/dp17034.pdf

Die Discussion Papers dienen einer möglichst schnellen Verbreitung von neueren Forschungsarbeiten des ZEW. Die Beiträge liegen in alleiniger Verantwortung der Autoren und stellen nicht notwendigerweise die Meinung des ZEW dar.

Discussion Papers are intended to make results of ZEW research promptly available to other economists in order to encourage discussion and suggestions for revisions. The authors are solely responsible for the contents which do not necessarily represent the opinion of the ZEW. 


\title{
The Development of Corporate Tax Structures in the European Union from 1998 to 2015 - Qualitative and Quantitative Analysis
}

\author{
Rainer Bräutigam*, Christoph Spengel ${ }^{\dagger}$, Kathrin Stutzenberger $^{\ddagger}$
}

This version: August 2017

\begin{abstract}
:
Ongoing tax reform processes, competitive pressures and the consequences of the financial and sovereign debt crisis have considerably shaped the tax systems of the Member States of the European Union in the last two decades. Our paper combines a qualitative and quantitative analysis of the development of European tax structures based on a unique and comprehensive dataset for the EU-25 Member States between 1998 and 2015. Especially among the EU-15 Member States, we still find evidence for the often-cited trend of tax rate cut cum tax base broadening. In this context, we identify interest deduction limitation rules and loss provisions as main drivers of tax base broadening. Furthermore, the quantitative analysis of effective tax burden scenarios shows that Member States seem to additionally rely on an increased taxation of dividends to balance possible revenue losses associated with reduced corporate income tax rates.
\end{abstract}

JEL Classification Code: H20, H25, K34

Keywords: Tax Policy, Corporate Taxation, European Union

* Rainer Bräutigam is a researcher at the Zentrum für Europäische Wirtschaftsforschung (ZEW) and at the University of Mannheim.

$\dagger$ Prof. Dr. Christoph Spengel holds the chair of Business Administration and Taxation II at the University of Mannheim, is a Research Associate at the Zentrum für Europäische Wirtschaftsforschung (ZEW) in Mannheim and Director of the MannheimTaxation Science Campus (MaTax).

* Kathrin Stutzenberger is a researcher at the University of Mannheim.

Acknowledgement: The authors gratefully acknowledge support from the MannheimTaxation Science Campus (MaTax), funded by the Leibniz Association, the State of Baden-Württemberg, and the participating institutions ZEW and University of Mannheim. 


\section{Introduction}

Issues in corporate taxation have definitely gained prominence during the last decade. Ever more new reports about low tax payments of highly profitable multinational corporations have initiated internationally coordinated ambitious corporate tax reform projects: Both the Base Erosion and Profit Shifting (BEPS) package of the OECD as well as the Action Plan of the European Commission aim at overcoming current deficits in corporate taxation and at making tax systems more sustainable for current challenges such as globalisation and digitalisation. ${ }^{1}$

Globalisation has not only led to an increased mobility of enterprises, but has likewise intensified the competitive pressure for countries to establish an attractive environment for investments of multinational corporations which is - among others - also influenced by the attractiveness of the corporate tax system. ${ }^{2}$ This is especially true within the European Union (EU) as direct taxation is one of few policy areas that remains within the sole national responsibility of each Member State. ${ }^{3}$ Several empirical studies found an increased tax competition within the EU in comparison to other world regions, ${ }^{4}$ which is also illustrated by current suspicions that certain Member States have illicitly granted specific tax incentives to single multinational corporations. ${ }^{5}$

Moreover, the EU faced several macroeconomic challenges in recent years with the economic crisis in 2008/2009 and the sovereign debt crisis from 2010 onwards. Both crises also impacted corporate tax policies in the Member States: During the economic crisis, many Member States introduced temporary tax measures to alleviate the consequences for enterprises. ${ }^{6}$ The sovereign debt crisis led to increased fiscal needs of Member States, which changed their corporate tax system voluntarily, or on request of international institutions to receive financial support.

The ongoing reform processes, the increasing globalisation and the crises had and continue to have a large influence on corporate tax policy in the EU. With our paper, we generally aim at a review and an analysis of the development of corporate tax systems in the Member States. Existing related studies mostly found a declining trend in corporate tax rates and broader tax bases ("tax rate cut cum tax base broadening"). ${ }^{7}$ However, these studies predominantly only

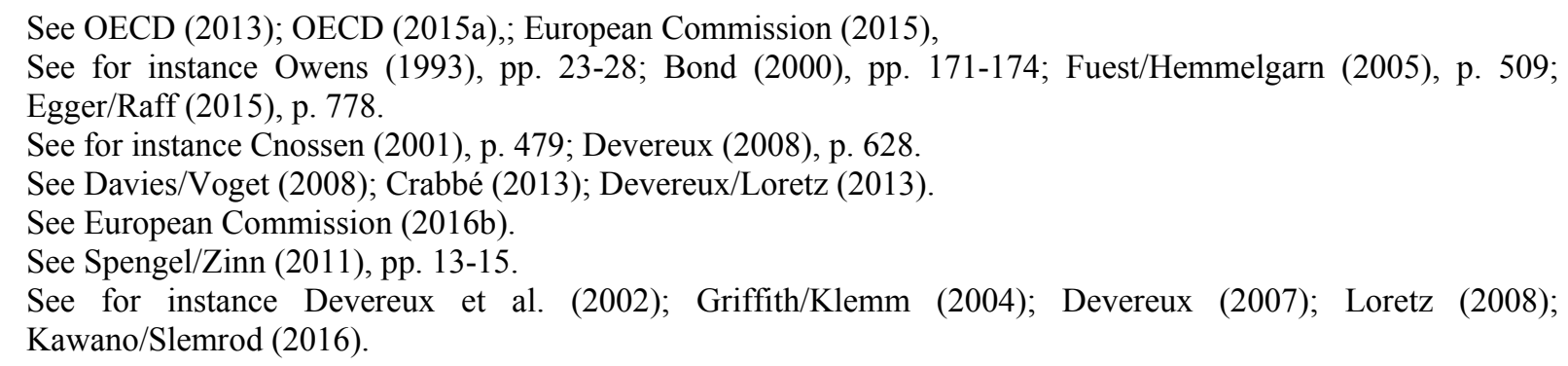


consider distinct OECD countries, cover a time horizon from the 1980s up to at best 2008 and assess the development of the corporate tax base only by depreciation rules for single assets.

We aim to close this gap by providing for a detailed qualitative and quantitative analysis of tax structures in the EU between 1998 and 2015. With the qualitative analysis, we try to ascertain whether the trend of tax rate cut cum tax base broadening is still of relevance today and which channels are in use from 1998 through 2015. More specifically, we will extend existing literature in four important ways: First, as existing studies only considered single countries among the OECD Member States, we are the first to provide for a comprehensive overview on the development of tax structures for the EU Member States over a long period. ${ }^{8}$ Second, we extend previous studies with regard to time as we consider the time period until 2015. This allows to include the developments of corporate income tax structures after the economic and sovereign debt crisis as well as first possible consequences of the international tax reform packages. Third, we provide for a much more detailed analysis of corporate tax base provisions: ${ }^{9}$ Especially in the present low-interest environment, the interest and liquidity advantages of depreciation rules are less important. ${ }^{10}$ In contrast, interest deduction limitation rules or limits to loss compensation might fully impede the deduction of business expenses and could therefore have much severe consequences. ${ }^{11}$ Additionally, we also consider the development of other relevant corporate taxes such as the German trade tax. Fourth, we take the development of shareholder taxation (dividend income) as a possible further channel of financing corporate tax rate cuts into account. As shareholder taxation is especially relevant for small and medium-sized enterprises that are also less mobile than multinational corporations, ${ }^{12}$ there might be incentives for Member States to attract comparatively mobile multinational enterprises by means of low corporate income tax rates and to compensate associated revenue losses through an increased dividend taxation of shareholders. ${ }^{13}$

The qualitative analysis is based on a comprehensive and hand-collected examination of the database of the International Bureau for Fiscal Documentation (IBFD), the IBFD's annual

\footnotetext{
See for instance Clausing (2007); Devereux (2007); Kawano/Slemrod (2016).

9 Despite a few exceptions, existing studies have predominantly only focused on depreciation rules. See for instance Devereux et al. (2002), pp. 457-460; Loretz (2008), pp. 645-647; Becker/Fuest (2011), pp. 581-583; Bond/Xing (2015), pp. 17-19. As an exception, Kawano/Slemrod (2016) provide for a very detailed description of tax base definitions.

10 See Spengel/Meier (2016), p. 498; Spengel et al. (2016a), p. 10.

11 See Spengel et al. (2010), p. 19.

12 See Sørensen (1995), p. 292. For corresponding Sweden-based empirical studies, see Edmark/Gordon (2013); Alstadsæter/Jacob (2016). According to the classical model of tax competition, it is assumed that the tax burden increasingly switches to immobile rather than mobile factors, see Bucovetsky/Wilson (1991); Zodrow (2010).

13 This is currently discussed in the United States, see Grubert/Altshuler (2016).
} 
European Tax Handbooks from 1998 through 2015 and additional sources. ${ }^{14}$ For reasons of clarity, our analysis is limited to the tax structures of the EU-25 Member States. This allows to analyse structural differences between the Member States among two subgroups, namely the EU-15 (Member States with accession date until 2004) and EU-10 (accession date in 2004). ${ }^{15}$ Since we focus on the development of tax structures within the EU, the EU-10 Member States will only be considered from their accession date onwards. ${ }^{16}$ Moreover, the tax data collection has been limited to the years 1998, 2002 and, after the accession of the EU-10 Member States, to two-year intervals (i.e. 2005, 2007, 2009, 2011, 2013 and 2015).

With the qualitative analysis of corporate tax base rules, it is possible to roughly estimate a tax base broadening or tax base narrowing effect. The overall consequences for the effective tax burden of corporations (development of tax base and tax rate) can only be measured by a quantitative analysis. As we consider multiple changes in corporate tax bases and other taxes that are relevant for the effective tax burden of corporations, it is necessary to use a simulation tool which allows such a detailed consideration of tax rules. Therefore, the quantitative analysis will be conducted with the European Tax Analyzer which allows for an exact quantification of the effects of single changes in tax base provisions and further incorporates other (profit) taxes at corporate level. Additionally, the taxation of shareholders can be taken into account as well.

The remainder of the paper is structured as follows. The qualitative analysis is conducted in sections 2 to 4 . Section 2 analyses the developments in corporate income tax bases and rates among the EU Member States. Subsequently, Section 3 and Section 4 extend the analysis to significant other corporate-level taxes and the taxation of dividends at shareholder level to evaluate other possible revenue channels. Subsequently, the results of the quantitative tax burden comparisons are presented in Section 5. Section 6 concludes.

\section{Development of Corporate Income Tax Structures in the EU}

For the development of tax structures in EU, we first consider trends in corporate tax bases. Along with the subsequent analysis of the developments in corporate income tax rates, we aim

14 Further important sources of information were Endres et al. (2007); Spengel/Zöllkau (2012); Endres/Spengel (2015); Spengel et al. (2016b).

15 We assume the simultaneous accession of ten Member States in 2004 to have a significant impact on European tax structures. Bulgaria, Romania and Croatia that joined the Union in later years (2007 and 2013) will not be part of the analysis.

16 For the EU-10 Member States, several studies have revealed strong declines in effective corporate tax rates prior to the accession to the EU, see for instance Bellak et al. (2009), pp. 272-273; Overesch/Wamser (2010), p. 430; Genschel et al. (2011), p. 591. 
to ascertain whether the trend of tax rate cut cum tax base broadening is still persistent in single Member States until 2015.

\subsection{Trends in Corporate Tax Bases}

Any analysis of the development of corporate tax base rules cannot be exhaustive as the tax base determination is a highly complex process. In previous literature, tax base broadening and narrowing has mainly been measured by the development of depreciation rules only. Despite the analysis of tax structures in several OECD countries by Kawano/Slemrod (2016), there is no comprehensive overview on the development of other tax base rules in the EU.

Due to its high relevance in prior literature, our analysis begins with the development of depreciation rules from 1998 to 2015. Subsequently, we consider rules for the valuation of inventory, interest deduction limitation rules, loss compensation provisions, notional interest deductions and the deductibility of other taxes. Based on a comprehensive analysis of all these tax base elements, it is possible to determine whether and how tax bases have become broader over time in a much more precise way as compared to previous literature.

\subsubsection{Depreciation Rules}

In existing literature, the base broadening effect of different depreciation methods has usually been measured by the present value of depreciation allowances. ${ }^{17}$ In contrast, our analysis is exclusively limited to the prevalence of different depreciation methods in the EU-25 Member States. By focusing only on the depreciation method itself, it is still possible to draw conclusions on whether tax bases become broader due to changes in the depreciation provisions. In addition, the heterogeneity of the depreciation methods used in the Member States can be analysed. In general, the straight line, accelerated, declining balance, immediate and pool depreciation method as well as a complete denial of depreciation allowances can be distinguished. In the following, we will consider the development of depreciation methods for five different assets: business equipment, patents, machinery as well as office and factory buildings. ${ }^{18}$

17 The calculation of the present value of depreciation allowances is usually based on the economic assumptions of Devereux et al. (2002), p. 458.

18 The economic lifetime is assumed to be 4 years for business equipment, 5 years for patents, 5 years for machinery as well as 50 years for office and factory buildings. 
Although the precise advantageousness of single depreciation rules depends on their specific design in terms of annual depreciation rates, it is nonetheless possible to draw some general conclusions on the favourability of certain methods: Immediate depreciation is most favourable from a tax perspective whereas the denial of depreciation is least favourable due to the full non-deductibility of acquisition costs. The straight line method allows only constant annual depreciation charges. The accelerated, declining balance and pool method usually result in higher depreciation rates during the first years. Therefore, the associated present value of depreciation allowances is regularly lower for the straight line method that - from a tax perspective - is thus considered as less favourable than the accelerated, declining balance and pool method. Higher depreciation allowances in the first years of the economic lifetime of an asset lead to positive interest and liquidity effects. Under the declining balance method, a constant depreciation rate is applied to the residual book value. In order to fully depreciate the asset, this method normally includes a switch to the straight line method. In contrast, the pool method does not allow for such a switch and the asset is thus in theory never fully depreciated. To further rank the accelerated, declining balance or pool method of depreciation, more information on their specific design such as the exact depreciation rate is required. In sum, the above depreciation methods can be classified into four categories of tax favourability as shown in Figure 1.

\section{Figure 1: Overview on the Tax Advantageousness of Single Depreciation Methods}

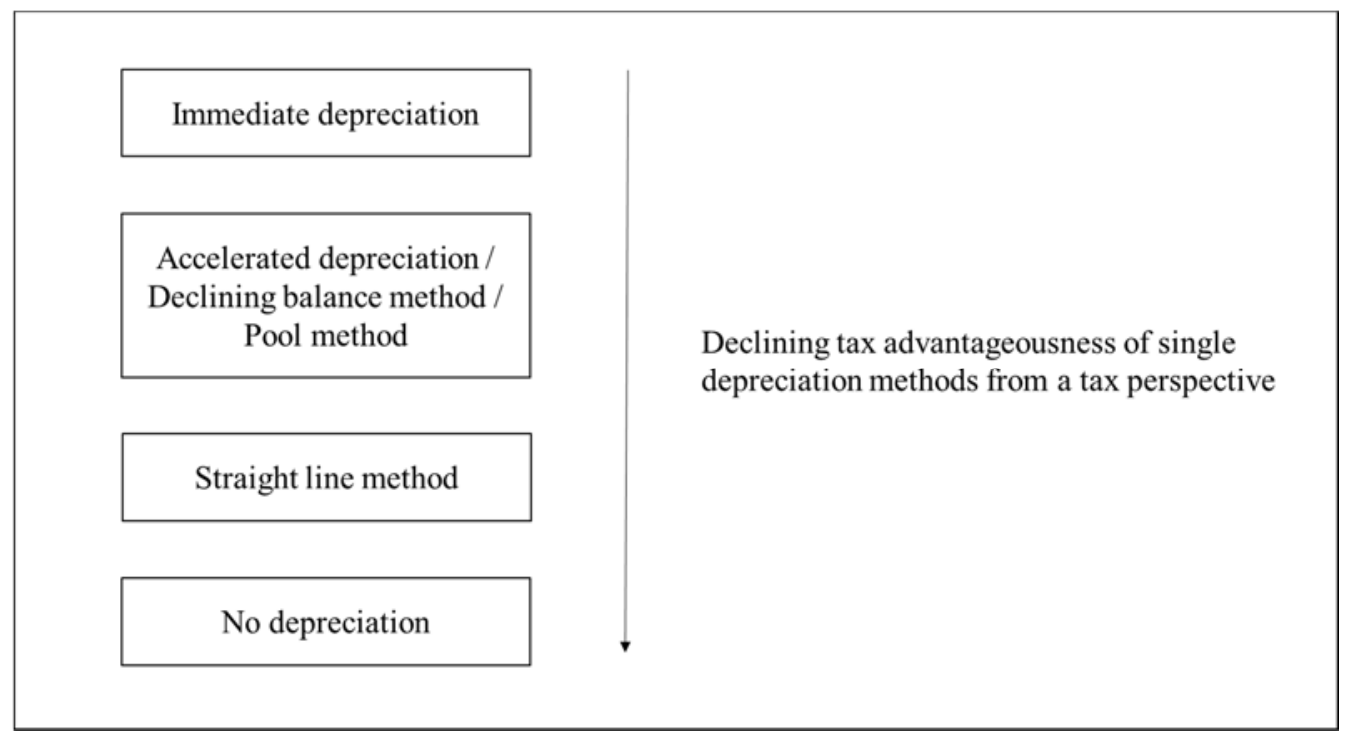

Most Member States allow more than one method for the depreciation of an asset. Our subsequent considerations are limited to the depreciation method that is most favourable from a tax perspective. The development of depreciation methods for the different kinds of assets is illustrated in Figure 2 below for the EU-15 (upper line) as well as EU-10 Member States (lower 
line) from 1998 through 2015. ${ }^{19}$ In each graph, the percentage amount of Member States that allow a specific depreciation method is shown for the different types of assets. ${ }^{20}$

Figure 2: Prevalence of Depreciation Methods across Asset Types

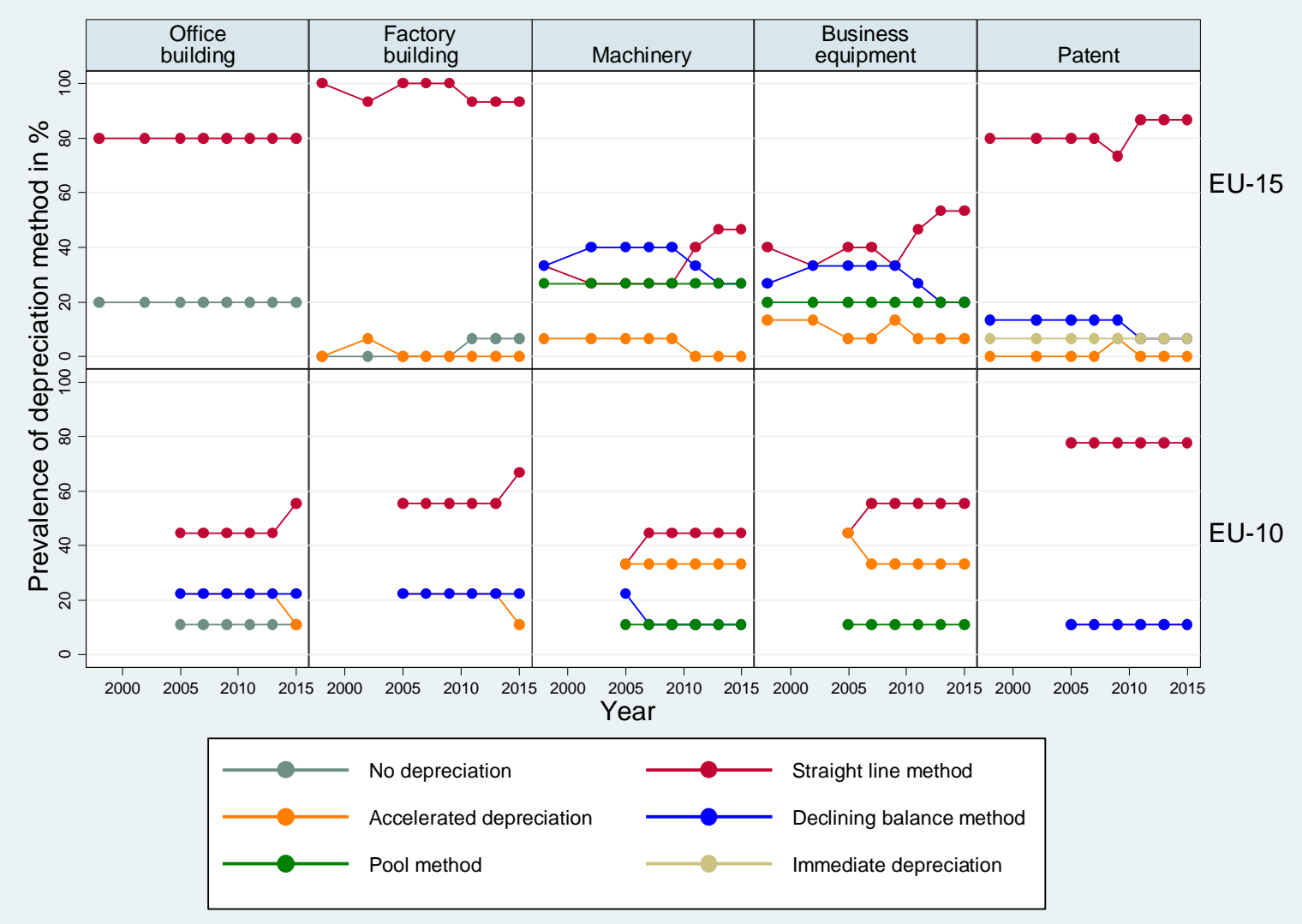

As regards the development of the provisions for the depreciation of office and factory buildings, the straight line method is most common among the EU-15. Only two changes can be observed for the depreciation of factory buildings from 1998 to 2015: On the one hand, accelerated depreciation is temporarily granted in Austria in 2002. On the other hand, the depreciation of such buildings is disallowed from 2011 on in the United Kingdom and thereby aligned to the treatment of office buildings. Similarly, Denmark, Ireland and Malta deny any depreciation of office buildings throughout the whole observation period. Among the EU-10, four different methods are in use for the depreciation of real property. The only change occurs

19 In case a change in depreciation method occurs, we only consider the change in the next year for which data are captured, i.e. a change in 1999 will be recorded in 2002.

20 In Estonia, profit determination rules are not relevant since corporate income tax is solely based on the amount of distributed profits; retained profits are subject to tax at a rate of $0 \%$. Therefore, for the EU-10, only nine Member States are considered. 
in 2015 in the Slovak Republic where office buildings have to be depreciated according to the straight line method instead of by the accelerated depreciation method.

For other fixed assets such as machinery and business equipment, a broader mandatory application of the straight line method can be observed in Germany (2011), Greece (2013) and Italy (2002 for business equipment, 2009 for machinery). In 2009, accelerated depreciation is temporarily available in Austria. ${ }^{21}$ Among the EU-10, the only change occurs in Poland where the declining balance method is abolished in 2007. Whereas the straight line method has always been the most common method from 2005 through 2015 among the EU-10, this is only the case from 2013 on among the EU-15.

Most Member States require the depreciation of patents according to the straight line method. There is almost no variation throughout the observation period. Only among the EU-15, the use of the straight line method is strengthened by a switch from the declining balance to the straight line method in the United Kingdom in 2011 and by the temporary availability of an accelerated depreciation scheme in Austria in 2009.

In sum, we find only limited evidence for tax base broadening by switches to a less favourable depreciation method across different kinds of assets. The constant high prevalence of straight line depreciation confirms the results of previous studies that found limited changes regarding depreciation methods and present values of depreciation since the $1990 \mathrm{~s} .{ }^{22}$ Especially in several of the EU-15 Member States, however, the prevalence of the already widespread straight line depreciation is further strengthened. It is interesting to see that the tax base broadening tendencies have especially occurred since 2009 during a period which has not yet been subject to analysis in previous studies.

\footnotetext{
21 At the same time, a switch from an accelerated depreciation to the use of the straight line method occurs in Italy such that the percentage of countries allowing accelerated depreciation remains constant.

22 See Devereux et al. (2002), p. 459; Bond/Xing (2015), p. 19.
} 
Figure 3: Prevalence and Development of Further Elements of Tax Base Definition

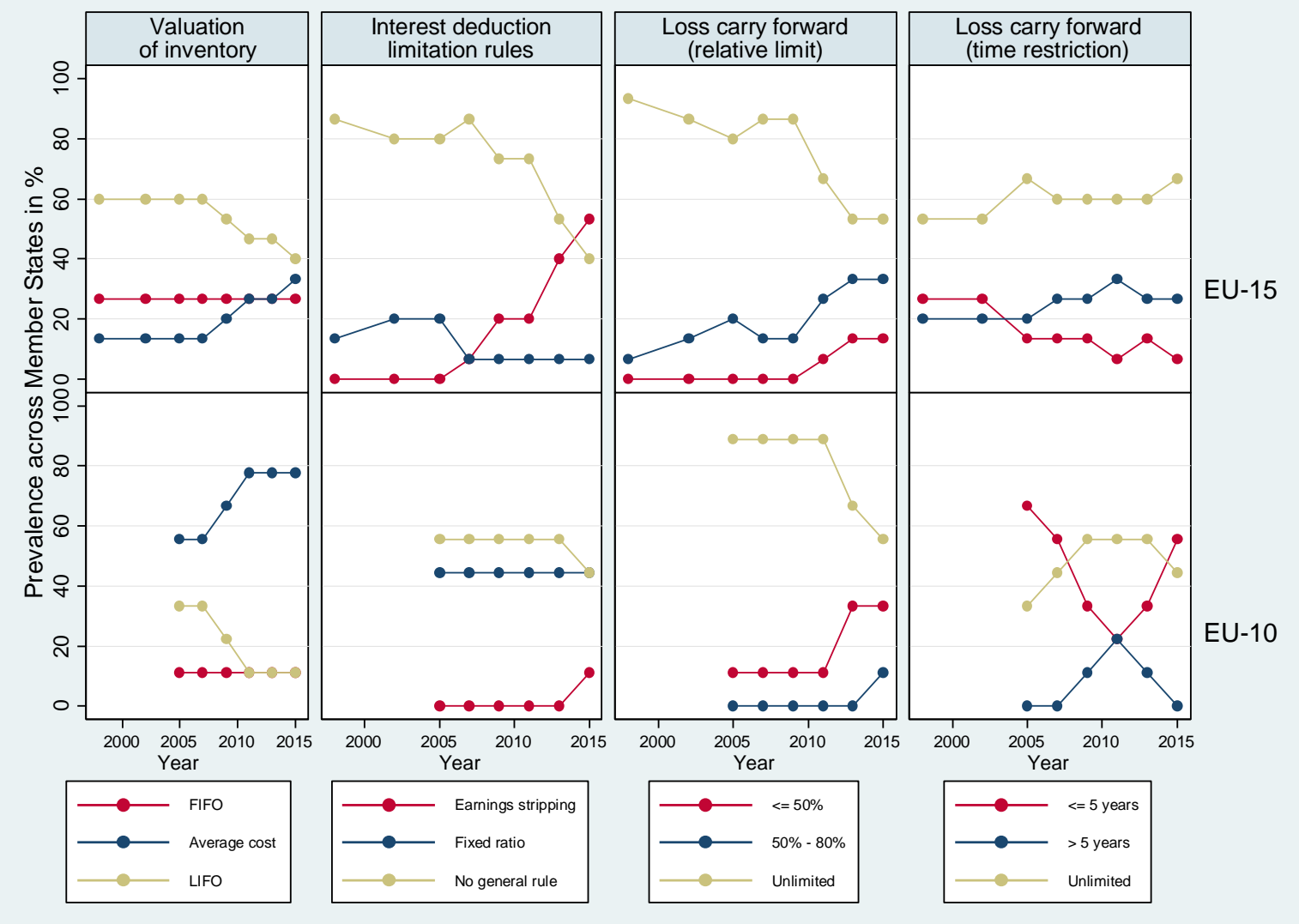

\subsubsection{Valuation of Inventory}

Generally, the LIFO (Last In First Out), FIFO (First In First Out) and the average cost method can be distinguished for the valuation of inventory. The use of the LIFO method is most tax beneficial in case factor prices increase since higher production costs are attributed to the goods sold. Moreover, the average cost method is more favourable than the FIFO method from a tax perspective. Again, as for the case of depreciation, taxpayers may usually choose between several options for the valuation of inventory within a country. In the following, we consider only the most tax efficient method.

Similar to the case of depreciation, the left graph in Figure 3 above presents the prevalence of different valuation methods across Member States. As evident from Figure 3, the use of the LIFO method has become less popular among both the EU-15 and EU-10 Member States. With Spain (2009), Portugal (2011) and Greece (2015) as well as Slovenia (2009) and Hungary (2013), five more Member States prescribe the use of the average cost method for the valuation 
of inventory, which indicates a tendency towards base broadening. The number of Member States that only allow the use of the FIFO method remains constant.

\subsubsection{Interest Deduction Limitation Rules}

Existing corporate income tax systems systematically favor debt over equity financing due to the deductibility of interest expenses whereas there is no similar relief for dividends as the cost of equity. ${ }^{23}$ For multinational corporations, cross-border debt financing is an important channel to exploit international tax rate differentials, which further strengthens the incentive to use debt financing. ${ }^{24}$ Hence, interest deduction limitation rules are not only considered as a means to achieve broader corporate tax bases, but - especially during recent years - have been used as instruments to limit cross-border shifting of taxable income. ${ }^{25}$

Member States follow two main approaches to limit an excessive tax deductibility of interest expenses: Under a fixed ratio approach, the deductibility of interest is restricted in case a firm's debt to asset ratio exceeds a certain safe harbor threshold whereas an earnings stripping rule limits the deductible part of excessive interest in relation to a profit figure such as EBITDA. ${ }^{26}$ Since profit measures are much more volatile than balance sheet items, earnings stripping rules are considered to be stricter than a fixed ratio approach. ${ }^{27}$ Several Member States apply further limitations to interest deductibility such as rather liberal administrative guidelines derived from jurisprudence. In the following analysis, only legal written rules in the tax laws of a country will be considered.

As it can be seen from the changes in the prevalence of the different types of interest deduction limitation rules in the second graph of Figure 3, there is an increasing tendency towards the introduction of earnings stripping rules starting in 2007 especially among the EU-15 Member States. Denmark was the first Member State to introduce such provisions in addition to an existing fixed ratio rule that has been implemented in 2002. Subsequently, seven other Member

23 See de Mooij (2011); Feld et al. (2013) for an overview of empirical studies on the impact of the so-called debt bias on corporate financing choices. In a few Member States, the debt bias is (partially) mitigated and the treatment of equity is adjusted to that of debt financing as a deduction for the notional return on equity is granted. The concept and prevalence of such notional interest deduction is elaborated in more detail in section 2.1.5.

24 See, for instance, Desai et al. (2004); Mintz/Weichenrieder (2010).

25 When interest deduction limitation rules were first introduced in Germany in 1994, for instance, one of the main objectives was to contribute to maintaining the level of tax revenue after a reduction of the statutory corporate income tax rate, see Bundesrat Drucksache 1/93, dated 04.01.1993. In 2008, interest deduction limitation rules were adjusted with the deliberate aim to limit cross-border debt shifting. For the history of German interest deduction limitation rules, see Ruf/Schindler (2015), pp. 22-24.

26 See Endres/Spengel (2015), pp. 368-370.

27 See OECD (2015b), p. 43. 
States introduced an earnings stripping rule. The number of EU-15 Member States that apply general interest deduction limitation rules increases to nine until $2015 .{ }^{28}$ Belgium is the only EU-15 Member State that applies a fixed ratio approach throughout the whole observation period.

Among the EU-10 Member States, there is no evidence for a similar development. Here, the fixed ratio approach is more common and is used in four EU-10 Member States from 2005 through 2015. Except for Poland where the safe harbor threshold is tightened from a debt-toequity-ratio of $3: 1$ to a ratio of $1: 1$ in $2015,{ }^{29}$ Member States do not implement changes to existing interest deduction limitation rules. In the subgroup of the EU-10 Member States, only the Slovak Republic newly introduces an earnings stripping rule in 2015. Thus far, it is the only EU-10 Member State with a profit-based limitation on interest deductibility.

The effects of interest deduction limitation rules could be alleviated to a certain extent in case Member States allow for a carry forward of non-deductible interest. Except for France and the Slovak Republic where non-deductible interest cannot be carried forward, the introduction of a carry forward of non-deductible interest usually coincides with the introduction of or switch to an earnings stripping rule. If a fixed ratio approach is in place, only Poland allows for a carry forward of non-deductible interest since 2015.

Interest deduction limitation rules may play a much more important role in the future. On 20 June 2016, the European Council adopted the Anti-Tax Avoidance Directive (ATAD) as part of the Commission's Anti-Tax Avoidance Package (ATAP). Article (Art.) 4 of the ATAD provides for an interest deduction limitation rule in the spirit of an earnings stripping rule. In the near future, the compulsory adoption of the earnings stripping rule as set out in Art. 4 of the ATAD and the associated base broadening effect will be especially relevant for the six EU-15 and five EU-10 Member States that - despite the above-mentioned developments - do not yet have a general interest deduction limitation rule in place. Although according to Art. 11(1) of the ATAD, all Member States will have to comply with the rules set out in the ATAD until 31

28 The trend towards the introduction of (stricter) interest deduction limitation rules in the EU-15 Member States may result from the European Court of Justice's (ECJ) ruling in the Lankhorst-Hohorst case (C-324/00) in 2002. As a consequence, not only Germany but also many other Member States had to adapt their interest deduction limitation rules. Whereas prior to the ruling, interest deductibility was usually only limited with regard to internal debt and foreign investments in many Member States, the rules have subsequently become stricter and more comprehensive.

29 Under the new rules, the threshold applies with regard to the borrower's equity, not to the share capital as provided under the old rules. 
December 2018, there is a longer transitional period for Member States with rules that are "equally effective to the interest limitation rule set out in [the] Directive". 30

Similar to the broad reasoning behind the implementation of interest deduction limitation rules, attempts to limit the deductibility of certain royalty payments have recently been made. The German legislator, for instance, has proposed a unilateral measure to at least partially deny the tax deductibility of royalty payments to a foreign entity with an IP box regime that does not comply with the so-called modified nexus approach as established within the framework of the OECD's initiative against Base Erosion and Profit Shifting (BEPS). ${ }^{31}$ In Austria, a comparable rule has already been in place since $2014 .^{32}$ It seems probable that other countries will adopt similar restrictions in the near future ${ }^{33}$ which - as shown above for the case of interest deduction limitation rules - may have an additional tax base broadening effect.

\subsubsection{Loss Compensation Rules}

In case a corporation incurs losses, there is usually no immediate loss compensation by means of a tax refund. Rather, losses can be set off against future or past profits (loss carry forward or loss carry back). ${ }^{34}$ Currently, all Member States allow a carry forward of losses. The rules in the Member States differ with regard to the amount of loss that may be used in future periods (relative or absolute limits) and the time constraints. The introduction of such limits also results in a tax base broadening. Moreover, the restrictions might result in foregone losses that cannot be recovered anymore. Relative limits for the use of loss carry forwards result in a definite minimum taxation of profits.

Especially among the EU-15 Member States, more and more countries have restricted the use of loss carry forwards to a certain percentage of profits since 2011 which can be inferred from the development shown in the third graph of Figure 3. In this regard, tax base broadening can

See Art. 11(6) of the ATAD. In this case, Member States have to apply the interest deduction limitation rules as set out in the ATAD only from 2024 on.

31 The OECD's BEPS initiative proposes, among others, measures to counter harmful tax practices. In the final report on Action 5, enhanced substance and transparency requirements are established that a taxpayer has to comply with in case he wants to benefit from tax advantages such as patent or IP boxes ("modified nexus approach"). The final legislation regarding the introduction of a royaltly deduction limitation rule into German tax law has been approved by the German Bundestag in June 2017 and will be applicable as of fiscal year 2018. See, among others, Benz/Böhmer (2017); Heidecke/Holst (2017a); Heidecke/Holst (2017b); Heil/Pupeter (2017); Schneider/Junior (2017) for an overview and criticism of the German rule to limit the deductibility of royalty payments.

32 See Trinks (2014), pp. 100-102 for an overview on the limitations to the deductibility of royalty payments in Austria.

33 See Heidecke/Holst (2017a).

34 See Endres/Spengel (2015), pp. 72-76, 98. 
be observed in roughly half of the EU-15 Member States. ${ }^{35}$ Germany (since 2004) and France (since 2011) have additional absolute limits in place which allow an unlimited use of the loss carry forward up to the absolute limit and the relative restriction applies to higher profits. Among the EU-10, the amount of loss carry forward has always been limited to $50 \%$ of profits in Poland from 1998 through 2015. In addition, restrictions are only implemented in Hungary, Lithuania and Slovenia. As a consequence, the amount of loss carry forward is limited in roughly half of the EU-25 Member States with corresponding splits also within both subgroups.

At the same time, however, several Member States have extended the allowable carry forward periods. The switch to a carry forward without restrictions in time in Italy and Spain and the extension of the allowable period in Portugal (from six to twelve years) coincides with the introduction of a relative limit to the carry forward amount. Among the EU-10, restrictions to the carry forward period are also abolished in Latvia, Lithuania and Slovenia. In contrast, a few Member States introduce new time restrictions for the use of loss carry forwards. Whereas among the EU-15 this is only the case in the Netherlands, among the EU-10, such restrictions are introduced in Cyprus and Hungary.

In general, the availability of a loss carry back is much less common. Only five of the EU-15 Member States (France, Germany, Ireland, the Netherlands and the United Kingdom) allow corporate taxpayers to carry back losses and set them off against previous years' profits between 1998 and 2015. Also in terms of a loss carry back, a tendency towards tax base broadening can be identified: Most Member States tighten the rules for loss carry backward in limiting the maximum carry back period from three years (France, the Netherlands) or two years (Germany) respectively to only one year.

\subsubsection{Further Tax Base Rules: Notional Interest Deduction and Deductibility of Other Taxes}

In the following, the development of two additional categories of tax base rules will be considered: the notional interest deduction and the deductibility of other taxes as both categories can have a major impact on the corporate tax base.

35 The amount of loss carry forward has been limited in Austria, Denmark, France, Germany, Italy, Portugal and Spain. 
A notional interest deduction represents one way to mitigate the so-called debt bias by granting a notional deduction for the cost of equity. ${ }^{36}$ In contrast to the previously considered rules, the introduction of a notional interest deduction has a tax base narrowing effect. ${ }^{37}$ From 1998 through 2015, only single Member States have implemented corresponding rules. Among the EU-15, Belgium and Italy introduced a notional interest deduction in 2007 and 2011, respectively. Although the introduction of a notional interest deduction was - among others motivated by the achievement of an equal treatment of debt and equity in both countries, their respective design differs considerably. ${ }^{38}$ Belgium allows the deduction for all equity whereas the Italian rule only offers the deduction on an incremental basis with a fixed reference year. Furthermore, in 1998, Italy had a dual income tax in place that had a similar effect. ${ }^{39}$ Among the EU-10 Member States, a notional interest deduction was temporarily in place in Latvia between 2009 and 2013 and it was introduced in Cyprus in 2015.

The alleviation of the debt bias might be much more popular in the near future as a notional interest deduction is an integral part of the draft directive on a Common Corporate Tax Base (CCTB) proposed by the European Commission in October 2016 (Allowance for Growth and Investment, "AGI"). ${ }^{40}$ Once adopted, this element of the directive would induce a base narrowing effect in all Member States.

Another way to achieve broader (narrower) corporate income tax bases is to deny (allow) the tax deductibility of other taxes such as real estate taxes or local profit taxes. ${ }^{41}$ It depends on the specific characteristics of these additional taxes whether the deductibility or non-deductibility has a major impact on the tax base. In this regard, only few changes are observed: In Luxembourg (2002) and Germany (2009), the deductibility of local profit taxes is completely denied. In Portugal, real estate taxes are not deductible from the corporate income tax base between 2002 and 2013, which also leads to broader corporate income tax bases. In contrast, the corporate income tax base is narrowed in Italy in 2009 through the introduction of a partial percentage deduction for local profit and real estate taxes. Among the EU-10 Member States, tax bases are broadened in Hungary as the deductibility of local profit taxes is limited (2011) whereas they become narrower in Cyprus through the deductibility of payroll taxes as of 2013.

\footnotetext{
See Devereux/Freeman (1991), pp. 2-4.

See Bond (2000), p. 172.

3 See Zangari (2014) for an overview on the design of the notional interest deduction in Belgium and Italy.

9 See Panteghini et al. (2012), p. 17.

See European Commission (2016a), pp. 10, 27-28.

41 An overview of changes in the structures of real estate taxes and important local (profit) taxes is presented in section 3 below.
} 


\subsubsection{Intermediate Conclusion}

The preceding analysis of the tax base structures in the EU-25 Member States from 1998 through 2015 has revealed important insights. Whereas country practice hardly changes with respect to depreciation rules, we find that other tax base provisions such as interest deduction limitation and loss compensation rules have considerably gained in importance and have become more relevant drivers of tax base broadening in the EU-15 and EU-10 Member States especially since 2007. In contrast, base narrowing policies such as the introduction of a notional interest deduction are not very common during the observed period.

The main channels for tax base broadening which have been identified in our analysis can have much severe consequences than depreciation rules for corporations. Different depreciation schemes will only induce timing effects; however, costs incurred may be fully deducted. With regard to loss compensation rules and interest deduction limitation rules, the ultimate tax deductibility may be (partially) refused depending on the financing structure or profitability of a firm. Corporate income tax would thus not be based on pure net profits anymore resulting in an indirect substance taxation. ${ }^{42}$ Corporations run the risk of losing interest expenses or loss carry forwards as potential deductions in case their economic situation does not change or upon changes of control. ${ }^{43}$

\subsection{Trends in Corporate Tax Rates}

After the description of the corporate income tax base rules over time, the trends in corporate income tax rates have to be analysed. Therefore, the development of average effective corporate income tax rates in the EU Member States is visualized in Table 1 below. The rates refer to the top marginal corporate income tax rates at federal level. Applicable surcharges that have the same base as the corporate income tax are included; local income taxes such as the German trade tax are excluded since they are subject to a separate analysis (see section 3 below).

42 See Spengel et al. (2010), p. 19.

43 See Spengel et al. (2010), pp. 24-27. 
Table 1: Average Effective Corporate Income Tax Rates in the EU-15 and EU-10 Member States

\begin{tabular}{|l|llllllll|}
\cline { 2 - 8 } \multicolumn{1}{c|}{} & 1998 & 2002 & 2005 & 2007 & 2009 & 2011 & 2013 & 2015 \\
\hline EU-15 & $35.1 \%$ & $31.0 \%$ & $28.4 \%$ & $27.1 \%$ & $25.6 \%$ & $25.2 \%$ & $25.4 \%$ & $24.8 \%$ \\
EU-10 & - & - & $20.4 \%$ & $20.5 \%$ & $20.0 \%$ & $19.2 \%$ & $19.6 \%$ & $19.4 \%$ \\
\hline
\end{tabular}

Source: Own calculations

During the period of our analysis, average effective corporate income tax rates decrease in both subgroups with a much more pronounced effect among the EU-15 Member States. There, tax rates decrease on average by 10.3 percentage points between 1998 and 2015 (by 3.6 percentage points between 2005 and 2015) in contrast to an average decrease of one percentage point in the EU-10 Member States (between 2005 and 2015). In general, the overall average tax level is substantially lower in the EU-10 Member States, which could explain the comparatively lower decrease in this subgroup.

Among the EU-15, the most noticeable tax rate reductions can be observed in Germany and Ireland as well as Denmark and the United Kingdom. In Germany, for instance, the tax rate is reduced by 31.7 percentage points from $47.5 \%$ in 1998 to $15.8 \%$ in 2015 . This strong decline is caused by the switch from an imputation system with different rates for retained and distributed profits that applied until 2001 towards the currently existing shareholder relief system. ${ }^{44}$ In Ireland, the corporate income tax rate of $32 \%$ in 1998 is reduced by $60.9 \%$ to $12.5 \%$ from 2003 onwards. ${ }^{45}$ Furthermore, above-average declines in corporate tax rates are observed in Denmark and the United Kingdom. In general, the declines in tax rates are stronger at the beginning of our observations. Whereas corporate tax rates decline until 2013 in Greece and until 2011 in Portugal, they increase again in subsequent years. This might still be viewed as measures to alleviate the effects of the aftermath of the sovereign debt crisis in two countries that were especially affected.

Among the EU-10, corporate tax rates also mostly decline, but remain constant in Latvia, Malta and Poland. In Cyprus and the Slovak Republic, however, tax rates increase between 2005 and 2015. Similar to the increase in tax rates in Greece and Portugal, the increase in Cyprus occurred

44 In 1998, a rate of $47.5 \%$ was applicable for the taxation of retained profits whereas a rate of $30 \%$ was applicable in case of profit distribution. When the effective corporate income tax rate was reduced to $15.8 \%$ in 2009 , the trade tax ceased to be a deductible expense for corporate income tax purposes.

45 Since we conduct a comprehensive, cross-sectoral analysis on corporate tax structures, we consider the general corporate income tax rate of 32\% applicable in Ireland in 1998 and disregard the reduced rate of $10 \%$ for manufacturing companies. 
in the context of measures to alleviate the immediate negative effects of the financial crisis in 2013.

\subsection{Analysis of the Interdependence between Trends in Corporate Tax Bases and Corporate Tax Rates}

Combining the results of the two previously separate analyses, we can conclude that there is still general evidence for tax rate cut cum tax base broadening policies. To draw countryspecific conclusions on the occurence of such policies, we provide for a standardized figure of tax base broadening relative to the percentage change in effective corporate tax rates in Figure $4{ }^{46}$ The standardized figure for tax base broadening is calculated as follows: For each Member State, each element of tax base definition is assigned a value of +1 in case base broadening occurs in that respective category and, in turn, a value of -1 is assigned if tax bases are narrowed. A value of 0 is assigned in case the respective tax base provision does not change and there is neither tax base broadening nor tax base narrowing. Finally, all values are added up to derive the standardized figure for tax base broadening. Appendix 1 provides a detailed overview on the parameters considered as well as the respective characteristics leading to the different base broadening values. To account for changes in tax rates irrespective of their initial level, we consider the percentage change in effective corporate income tax rates.

To decide on base broadening or base narrowing, we compare the respective national provisions at two points in time for each category. The periods from 1998 through 2007 (only EU-15) and from 2007 to 2015 (both EU-15 and EU-10) are considered as opposed to the long-term analyses in existing literature. This split is relevant to distinguish potential effects of the economic crisis in 2008/2009 and the following sovereign debt crisis which had substantial impact on economic conditions in the EU Member States. Considering 2009 as the base year is not sensible as many countries implemented crisis-related ad-hoc tax measures. ${ }^{47}$

Figure 4 below illustrates the changes in tax base relative to the percentage changes in tax rate for both the EU-15 and EU-10 Member States. Depending on the location of the country data points, conclusions on the tax policy of the respective Member State can be drawn: In case a country simultaneously lowers its tax rate and introduces provisions that lead to broader tax bases (tax rate cut cum tax base broadening), the data point would be situated in the lower right

46 Doing so, we follow an approach similar to Becker/Fuest (2011) and Kawano/Slemrod (2016).

47 For instance, the availability of accelerated depreciation in Austria in 2009 mentioned in section 2.1.1. constitutes such a crisis-related measure. 
quadrant. In case only one parameter is changed, the data point would be located on one of the axes. It would be located at the intercept of both axes if neither of the considered dimensions (tax base rules and tax rate) change.

\section{Figure 4: Change in Effective Corporate Income Tax Rates (in \%) in Relation to Number of Tax Base Broadening Measures}

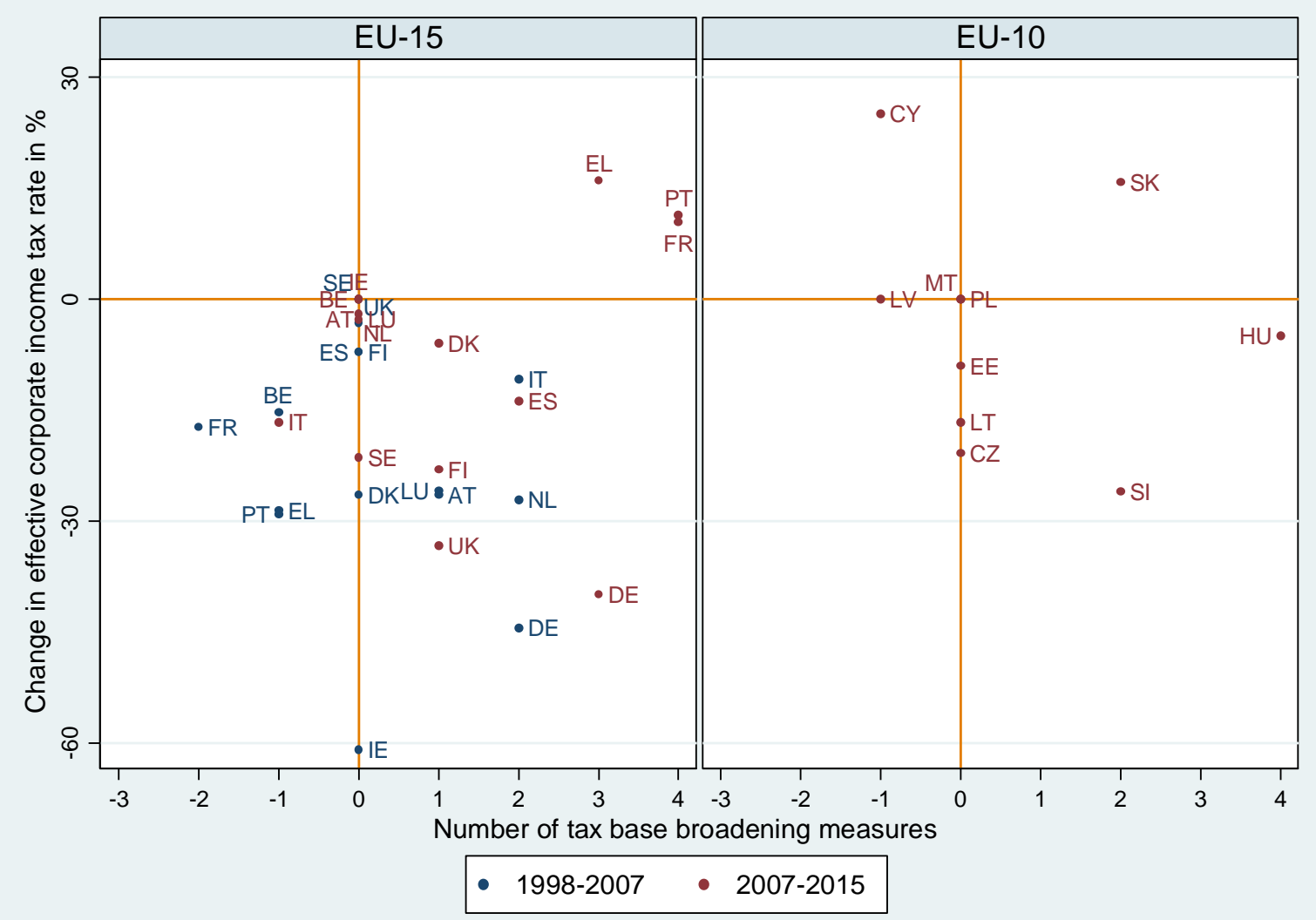

Among the EU-15 Member States, two different trends can be observed from 1998 through 2007 and from 2007 through 2015. As evident from the left part of the above illustration, tax rates were reduced and tax bases were broadened in five Member States, namely Austria, Germany, Italy, Luxembourg and the Netherlands between 1998 and 2007. The effect of tax base broadening is especially distinct for instance in Germany and the Netherlands with an overall base broadening score of 2 that stems from changes in the provisions regarding the treatment of losses (see chapter 2.1.4. above). At the same time, the decreases in tax rates were accompanied by reforms that - according to our measure - in sum led to narrower corporate tax bases in Belgium, France, Greece and Portugal. In the remainder of EU-15 Member States, there is no effect on corporate tax bases due to lack of corresponding reforms. ${ }^{48}$ Except for

48 It could also be that tax base broadening and tax base narrowing measures cancel out and lead to a base broadening score of 0 . See Appendix 1 for details on the description and specification of base broadening parameters. 
Sweden where the tax rate remains unchanged from 1998 through 2007, corporate income tax rates uniformly decrease in all other EU-15 Member States during the first period.

During the second period (2007-2015), more tax base broadening measures are introduced especially in Member States where no base broadening was observed during the previous period or where tax bases were then even narrowed. Also, the overall magnitude of tax base broadening appears to be larger. Tax rate cut cum tax base broadening reforms are observed in five Member States (Denmark, Finland, Germany, Spain, the United Kingdom). Although Member States still mostly reduce corporate income tax rates, in contrast to the previous period, there are three Member States where effective corporate income tax rates even increase (France, Greece, Portugal). Interestingly, the increases are observed in those Member States where tax base broadening is also most pronounced. During the second observation period, thus, base broadening is not necessarily associated with lower tax rates. As concluded in chapter 2.2. above, this may at least in part be intended as a countermeasure to alleviate the effects of the sovereign debt crisis.

The development of tax rates and tax bases among the EU-10 Member States from 2007 through 2015 does not provide a uniform picture. Only Slovenia and Hungary simultaneously lower their corporate tax rates and implement reforms that lead to broader tax bases. Among all Member States considered, only in Cyprus a reverse effect can be observed since a higher corporate income tax rate is applied to a narrower corporate income tax base. In half of the EU-10 Member States, there is even no tax base effect. This might coincide with the systematically lower corporate income tax rates in the EU-10 subgroup: It has been argued in previous literature that these low rates are combined with very broad tax bases and restrictive loss compensation rules leaving little room for further tax base broadening. ${ }^{49}$

Overall, our observations confirm the persistence of the trend of tax rate cut cum tax base broadening from 1998 through 2015. Especially when looking at different partial periods, interesting effects are apparent in the subgroup of the EU-15 Member States. Although there are countries that reduce corporate tax rates and simultaneously broaden corporate tax bases in both partial periods, the magnitude of base broadening is stronger from 2007 through 2015 . Furthermore, reforms leading to broader corporate income tax bases are accompanied with higher corporate income tax rates in Member States such as Greece or Portugal that were particularly affected by the economic and subsequent sovereign debt crisis.

49 See Jacob et al. (2011), pp. 75-79. 


\section{Other Corporate (Profit) Taxes}

Apart from corporate income tax, most Member States levy further corporate profit and nonprofit taxes such as real estate taxes, local profit taxes, payroll taxes or net worth taxes which can be highly relevant for the effective tax burden of corporations. In the following analysis, only the general prevalence and design of those other taxes including the underlying rates will be discussed. The aim is to gain insights on whether a similar development as with regard to corporate income tax can be identified. For a detailed overview on the specific design of the tax bases of single taxes in the different Member States, reference is made to the related literature. ${ }^{50}$ In general, real estate taxes are levied in almost every Member State. Among the EU-15, both land and buildings are included in the real estate tax base. The respective value of the tax base is determined either with reference to market values or based on historical cost. In contrast, among the EU-10, real estate taxes are not levied in Malta and Slovenia. Moreover, only land is included in the real tax base in the Slovak Republic which results in a narrower tax base than in the remainder of countries. In the Czech Republic, Hungary, Poland and the Slovak Republic, the value of the tax base is determined according to the square footage of the property. This valuation standard is not found among the EU-15 Member States.

Local profit taxes are levied in only five of the EU-15 Member States (France, Germany, Italy, Luxembourg and Spain). Among the EU-10 Member States, only Hungary levies a local profit tax. Although local taxes can have similarities to the determination of the corporate income tax base, local tax bases are usually much broader. In Luxembourg, however, the municipal business tax base corresponds to the corporate income tax base since 2011. As a whole, there is no uniform development of local tax structures across Member States. A trend of broader tax bases and lower tax rates is only found in Luxembourg where the abolition of the percentage deduction for property assets leads to a broader tax base of the municipal business tax (Impôt Commercial Communal sur le Bénéfice) as of 2011. The underlying tax rate decreases from $10 \%$ in 1998 to $7.5 \%$ in 2007 and $6.75 \%$ in 2009 .

Germany is the only Member State where the local trade tax (Gewerbesteuer) has become a more important determinant of the effective tax burden between 1998 and 2015. This can be attributed to two different developments: First, the tax base of the Gewerbesteuer has become broader especially since 2009 due to a tightening of the add back provisions for instance in case of financing expenses. Second, the increasing relevance can be explained by the interdiction to 
treat the trade tax as a deductible expense for corporate income tax purposes. This shift was combined with a reduction of the trade tax rate from $5 \%$ to $3.5 \%$. Furthermore, limitations to the use of loss carry forwards within the trade tax also have a base broadening effect. Moreover, the average municipal factor rate which is combined with the trade tax rate to achieve the overall effective trade tax rate has increased from $426 \%$ in 1998 to $447 \%$ in $2015 .{ }^{51}$

On the contrary, the importance of local profit taxes decreases in Italy and Hungary: In Italy, the tax base of the regional tax on productive activities (Imposta Regionale sulle Attività Produttive, IRAP) has become narrower with the introduction of a lump-sum deduction for personnel cost in 2005. From 2015, all actual labour cost may be deducted which might further narrow the IRAP base. Additionally, the IRAP rate is decreased from $4.25 \%$ to $3.9 \%$ as of 2009 . In Hungary, the abolition of the add-back provision for $50 \%$ of interest as of 2007 leads to a narrower tax base of the local business tax (Helyi Iparüzési Adó). The tax rate remains unchanged.

A special development is observed in France where the Taxe Professionnelle was based on the value of real property and machinery until 2011 and thus shared some characteristics of a wealth tax. As of 2011, the former Taxe Professionnelle was replaced by a new, two-fold local tax (Contribution Economique Territoriale, CET) consisting of a land contribution for enterprises based on the rental value of real property and a contribution on the value added defined as net sales minus the value of inventory. At the same time, the tax rate increases from $23.6 \%$ in 1998 to $25.7 \%$ in 2015. In Spain, the local business tax (Impuesto sobre Actividades Económicas, IAE) remains unchanged from 1998 through 2015.

The prevalence of payroll taxes is low among both the EU-15 and EU-10 Member States; only Austria, Cyprus, France and the Slovak Republic levy or levied such taxes from 1998 through 2015. In all Member States, payroll taxes are based on labour costs after social security payments. Despite the abolition of the payroll tax in the Slovak Republic in 2009 and minor changes in tax rates, it is not possible to identify a common trend.

At corporate level, a net wealth tax is only imposed in Luxembourg. Apart from the exclusion of intangible property from the net wealth tax base in 2009 , there are no further changes to the net wealth tax base or rate.

51 Average municipal factor rates are gathered from an annual series of the Institut für Finanzen und Steuern (ifst), see for instance Andrae (2015). 
As a whole, no general conclusion regarding a higher or lower importance of other corporate profit or non-profit taxes is possible. An important insight from the preceding analysis is, however, that the respective tax structures of the Member States remain predominantly constant. Apart from the abolition of the payroll tax in the Slovak Republic and a major reform concerning the local profit tax in France, no other significant changes are observed. In case Member States impose further taxes at corporate level, they predominantly seem to maintain these taxes and refrain from major changes. Vice versa, no Member State newly introduces any of the taxes considered during the relevant time period.

\section{Shareholder Taxation}

The observed decline in corporate income tax rates can be related to the competition for mobile investment of multinational corporations among countries. ${ }^{52}$ As regards multinational corporations, it is assumed that shareholder taxation has no effect on corporate investment decisions since tax consequences at shareholder level are largely unknown. ${ }^{53}$ For small and medium-sized firms, however, the taxation of shareholders has to be taken into account. ${ }^{54}$

Based on these arguments, an additional instrument to balance potential tax revenue losses from declines in the corporate income tax rates besides broader corporate tax bases could be possible: the increase in personal income tax rates on dividends or a general increase in personal income tax rates. ${ }^{55}$ With a reduction of the corporate income tax rate and an increasing tax rate for the dividend income of shareholders, the overall tax burden of small and medium-sized companies could be kept constant (or is even increasing) whereas the country nevertheless becomes more attractive as an investment location for multinational corporations.

In case a Member State reduces its corporate income tax rate while the personal income tax rate on dividends remains unchanged, the relative share of dividend taxation with regard to the total tax burden increases. ${ }^{56}$ If the total tax burden is supposed to remain constant, an increased taxation of dividend income at shareholder level would be necessary to compensate for the decrease in corporate income tax rates. The following calculation example in Table 2 illustrates this relationship. For simplicity, we assume a classical system for the taxation of dividends.

\footnotetext{
2 See Feld/Heckemeyer (2011), pp. 234-237 for a review of the corresponding literature.

See, for instance, Commission of the European Communities (1992), p. 71; Devereux/Griffith (2003), p. 115.

See, for instance, Spengel/Bergner (2015), p. 13.

5 See Grubert/Altshuler (2016), pp. 3-5 for a recent proposal of such reform in the United States.

56 See Spengel (2008), p. 54.
} 
Table 2: Calculation Example on the Interdependency of Decreases in the Corporate Income Tax Rate and a Constant Total Tax Burden

\begin{tabular}{|c|c|c|c|}
\hline & Base Case & $\begin{array}{r}\text { Reduction } \\
\text { CIT Rate }\end{array}$ & $\begin{array}{l}\text { Necessary } \\
\text { Increase in } \\
\text { PIT Rate } \\
\text { (Dividends) }\end{array}$ \\
\hline CIT Rate & $40.0 \%$ & $30.0 \%$ & $30.0 \%$ \\
\hline PIT Rate (Dividends) & $20.0 \%$ & $20.0 \%$ & $\underline{31.4 \%}$ \\
\hline \multicolumn{4}{|l|}{ Corporate Level } \\
\hline Profit before Tax & 100.0 & 100.0 & 100.0 \\
\hline Tax Burden & 40.0 & 30.0 & 30.0 \\
\hline Profit after Tax & 60.0 & 70.0 & 70.0 \\
\hline \multicolumn{4}{|l|}{ Shareholder Level } \\
\hline Dividend Income & 60.0 & 70.0 & 70.0 \\
\hline Tax Burden & 12.0 & 14.0 & $\underline{22.0}$ \\
\hline Profit after Tax & 48.0 & 16.0 & 48.0 \\
\hline Total Tax Burden & 52.0 & 44.0 & 52.0 \\
\hline thereof: Share CIT & $76.9 \%$ & $68.2 \%$ & $57.7 \%$ \\
\hline thereof: Share PIT (Div.) & $23.1 \%$ & $31.8 \%$ & $42.3 \%$ \\
\hline
\end{tabular}

In the calculation example, a decrease in corporate income tax rates of ten percentage points must be compensated by an increase in the dividend tax rate of more than ten percentage points to maintain a constant total tax burden. The relative share of the shareholders' tax burden with regard to the total tax burden already increases only due to the decrease in the corporate income tax rate.

When analysing the development of personal income tax rates on dividends, the integration of corporate and personal income tax systems needs to be considered as well. Since 1998, the widely-used (full) imputation system has been replaced in most Member States by the separate taxation of dividend income in a shareholder relief system. ${ }^{57}$ Among the EU-15, this trend is particularly obvious between 2002 and 2007. Only in Greece, dividends have been completely exempt prior to the introduction of a shareholder relief system in 2011. Since 2011, all Member States except for Ireland apply a shareholder relief system. In Ireland, a classical system is in place, which results in a full economic double taxation of profits. Among the EU-10, this trend is much less pronounced as most Member States already have a shareholder relief system in place before 2005. An exemption is Latvia where the taxation of dividend income has been newly introduced as of 2011 within the framework of a shareholder relief system.

57 See Endres/Spengel (2016), p. 145. 
In the following, Figure 5 illustrates the percentage change in effective corporate income tax rates and effective personal income tax rates on dividends for the periods from 1998 through 2007 and 2007 through 2015 and the two subgroups of EU Member States. For the effective dividend tax rates, if applicable, we consider the highest marginal tax rate. In case a Member State newly introduces the taxation of dividends, the change is standardized at $100 \%{ }^{58}$ Furthermore, we account for reliefs that result, for instance, from the application of a (full) imputation or shareholder relief system..$^{59}$

\section{Figure 5: Changes in Effective Corporate Income Tax Rates in Relation to Changes in} Effective Personal Income Tax Rate on Dividends (in \%)

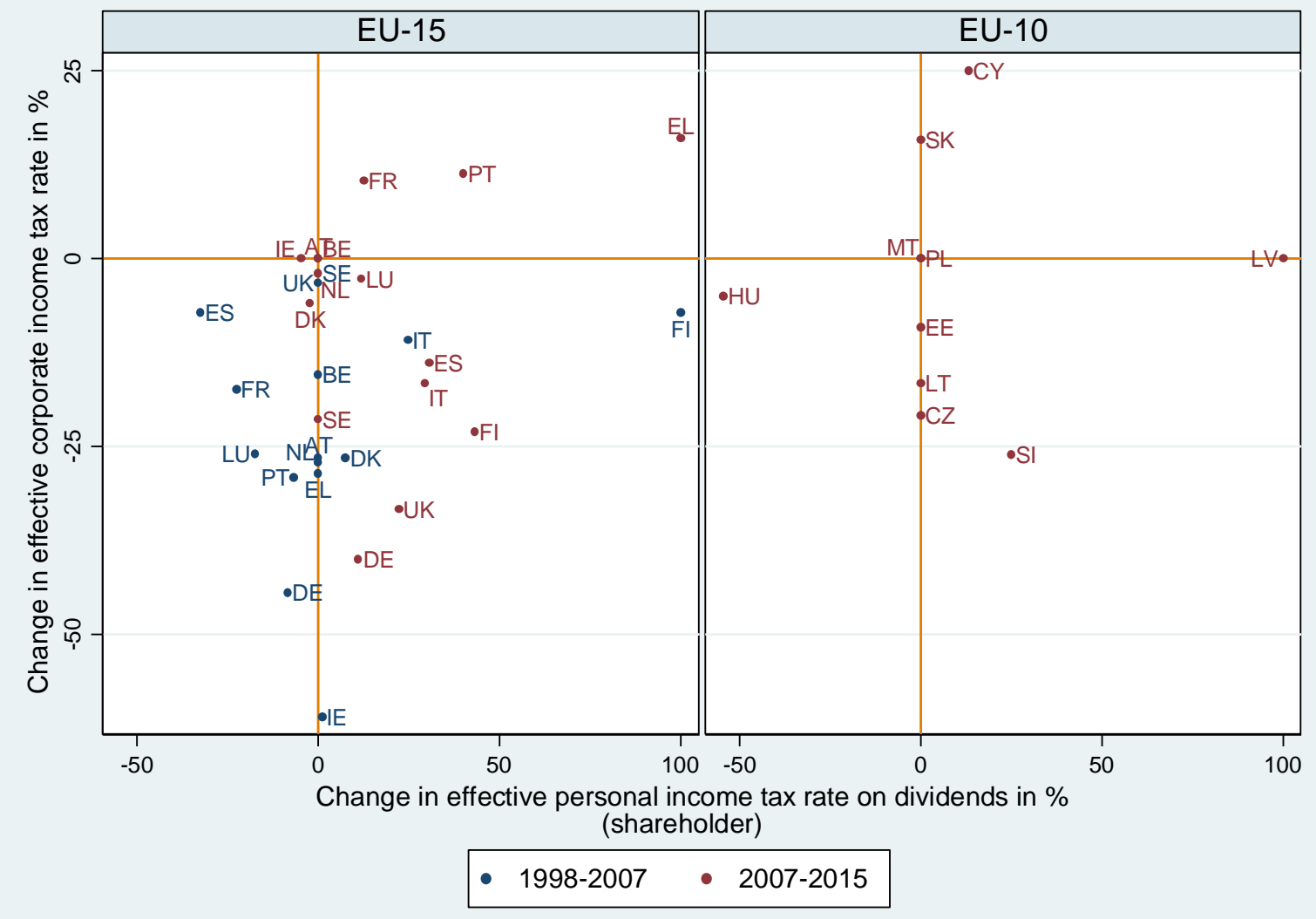

Regarding the effective personal income tax rates on dividends, a similar development as with respect to corporate income tax bases is observed among the EU-15 Member States. From 1998 to 2007, there are several Member States where both corporate and personal income tax rates on dividends decrease. These Member States can be found in the lower left quadrant. During the subsequent period, there is an opposite development in more and more Member States with

59 Exemplary computations for the effective dividend tax rates in Italy in 1998 and 2015 can be found in Appendix 2. 
decreases in corporate income tax rates and increases in personal income tax rates on dividends. In three Member States (France, Greece and Portugal), both rates increase. These Member States have also reacted with broader corporate income tax bases to the increase in corporate tax rates (see section 2.3.).

As for the analysis of changes in corporate income tax rates and bases, the development among the EU-10 Member States does not show a uniform trend. In six of the EU-10 Member States, dividend tax rates remain unchanged between 2007 and 2015. In Cyprus, Latvia and the Slovak Republic, dividend tax rates increase whereas in Hungary, both corporate and personal income tax rates decrease.

As a whole, increases in effective dividend tax rates are also likely to represent a rather new option to counter possible tax revenue losses from decreases in corporate income tax rates. Still, this holds true only for the EU-15 Member States from 2007 through 2015.

\section{Quantitative Analysis of the Development of Tax Structures in Europe}

\subsection{Need for a Quantitative Analysis}

For the qualitative analysis concerning the prevalence of tax base broadening, we made the simplifying assumption of equally ranked base broadening parameters. ${ }^{60}$ Although this allows to identify general trends in corporate tax structures in the EU-25 Member States, we cannot differentiate the impact of different base broadening tax reforms. Moreover, it is unclear whether those reforms led to an overall decline in the effective corporate tax burden taking into account the development of corporate tax rates and other relevant taxes. Hence, to get a better understanding of the overall impact of the qualitative changes on the effective tax burdens of corporations, we further conduct a quantitative tax burden assessment. In this regard, we rely on the European Tax Analyzer as a simulation tool that allows the implementation of all tax base changes (e.g. loss compensation rules) and other profit taxes (e.g. German trade tax) analysed in the previous sections.

In the following, first, the underlying model framework of the European Tax Analyzer is presented in short. Subsequently, we will retrace general developments in effective tax burdens for the EU-15 and EU-10 Member States for the periods 1998 to 2015 or 2005 to 2015,

60 Based on the underlying assumptions for the qualitative analysis in section 2.3., a multitude of combinations of tax reforms could result in the same standardized base broadening value as we assume each base broadening measure to account for an absolute value of 1 without differentiating their potential impact on corporate tax bases. 
respectively, based on the assumption of a large EU-28 average model corporation. In addition to the consideration of group averages, we analyse the developments in single Member States. Furthermore, the robustness of the identified general trends for the average model corporation will be assessed in a sensitivity analysis with varying economic parameters such as the equity ratio.

\subsection{Methodology of the European Tax Analyzer}

The following description of the methodology and underlying assumptions of the European Tax Analyzer is adapted from the explanations in Spengel et al. (2012, pp. 203-206). The European Tax Analyzer is a computer-based model-firm approach for the calculation and comparison of effective average tax burdens for companies facing different tax systems in Europe. The effective average tax burden is derived by simulating the development of a company over ten simulation periods. It is expressed as the difference between the pre-tax and post-tax value of the company at the end of the simulation period and states the central outcome variable of the model. The value of the company is represented by its equity including the capital stock and the cumulative net income generated in each of the ten simulation periods. In order to determine the post-tax value, the tax liabilities of each of the ten periods are derived, taking all taxes that may be influenced by investments and financing decisions at the corporate level into account (e.g. corporate income tax, real estate taxes, payroll taxes, trade taxes, net wealth taxes or surcharges). In this regard, the European Tax Analyzer allows to implement all major tax base parameters in a very detailed manner (e.g. depreciation schemes, interest deduction limitation rules, loss provisions).

For the calculation of the effective tax burden, the model framework of the European Tax Analyzer assumes various types of underlying model corporations based on balance sheet and income statement data from the AMADEUS database of the Bureau Van Dijk. ${ }^{61}$ The following calculations rely on a large EU-28 average model corporation based on financial data of $2011 .{ }^{62}$ Thus, the assumed EU-28 average model corporation ignores country- and industry-specific effects on pre-tax data: As the balance sheet, profit and loss account and corporate planning (e.g. regarding production, sales, staff, financing or procurement) of the model corporation are

61 For a detailed overview on the generation of the model corporations, see Spengel et al. (2015), Annex 1, pp. 5870. The AMADEUS update as of September 2013 has been used for the generation of the model corporations.

62 Besides the generation of an EU-28 average model corporation across all economic sectors, industry- or sizespecific model corporations have been generated. However, these will not be part of the quantitative analysis of this paper. 
given, differences between pre- and post-tax data can be attributed to the effects of countryspecific tax rules only.

Table 3 sets out the balance sheet of the generated EU-28 average model corporation. It shows the different types of investments as well as their sources of finance. In addition, the structure of the model firm and its characteristics, expressed in common financial ratios, are presented in Table 4.

Table 3: Tax Balance Sheet of the EU-28 Average Model Corporation (Period 6 of 10)

\begin{tabular}{|c|c|c|c|}
\hline Assets & EUR & Equity and Liabilities & EUR \\
\hline A. Fixed Assets & & A. Equity & \\
\hline I. Intangible Assets & $5,199,376$ & I. Subscribed capital & $21,305,895$ \\
\hline II. Tangible Assets & & II. Revenue reserves & $41,504,474$ \\
\hline 1. Land, similar rights and buildings & $17,604,472$ & III. Net profit/Net loss & $10,383,662$ \\
\hline 2. Technical equipment and machinery & $13,320,641$ & B. Provisions & \\
\hline 3. Factory and office equipment & $10,226,065$ & I. Provisions for pensions and other obligations & 0 \\
\hline III. Financial Assets & & II. Other Provisions & $8,062,568$ \\
\hline 1. Participating interests & $11,167,634$ & & \\
\hline 2. Long-term receivables & $1,240,848$ & C. Creditors & \\
\hline B. Current Assets & & I. Long-term bank loans & $19,937,409$ \\
\hline I. Stocks & $27,361,625$ & II. Amounts owed to shareholders & $22,660,522$ \\
\hline II. Trade debtors & $41,937,873$ & III. Trade creditors & $15,709,464$ \\
\hline IV. Securities, cash, deposits & $43,890,654$ & IV. Short-term bankloans and overdrafts & $32,385,194$ \\
\hline Total & $171,949,188$ & Total & $171,949,188$ \\
\hline
\end{tabular}

Table 4: Financial Ratios of the Implemented EU-28 Average Model Corporation (Period 6 of 10)

\begin{tabular}{|c|c|c|c|c|c|}
\hline $\begin{array}{c}\text { Intensity of } \\
\text { Machinery }\end{array}$ & $\begin{array}{c}\text { Profit to Turnover } \\
\text { Ratio }\end{array}$ & $\begin{array}{c}\text { Return on } \\
\text { Equity }\end{array}$ & $\begin{array}{c}\text { Equity } \\
\text { Ratio }\end{array}$ & $\begin{array}{c}\text { Stock } \\
\text { Intensity }\end{array}$ & $\begin{array}{c}\text { Personnel } \\
\text { Intensity }\end{array}$ \\
\hline $23.93 \%$ & $4.95 \%$ & $16.53 \%$ & $42.57 \%$ & $15.91 \%$ & $11.42 \%$ \\
\hline
\end{tabular}

The definition and description of the model firm requires several assumptions regarding the underlying economic conditions and further planning parameters:

- Expected economic lifetime for assets: 50 years for both production buildings and office buildings; 5 years for patents and concessions; 4 years for plant and 5 to 10 years for machinery; 9 years for office furniture and fixtures; zero for both financial assets and stocks; 
- Depreciable assets are assumed to be run down at the end of their expected economic life and replaced by new asset, based on the historical cost of the deposited assets adjusted for inflation. Thus, the initial capital stock remains at least constant;

- The goods produced are assumed to be either stocked or sold on the market in the period of production, so multi-period production is possible;

- Inflation rates: ${ }^{63}$ price index for basic material (2.5\%); consumer price index $(2.7 \%)$; price index for wages $(2.2 \%)$; price index for investment goods $(2.7 \%)$; price index for real estate $(2.5 \%)$;

- Interest rates for creditors and debtors: ${ }^{64}$ short-term debt claim (1.1\%); long-term debt claim (2.5\%); short-term liabilities (3.9\%); long-term liabilities (3.5\%).

In terms of a complete and comprehensive quantitative analysis of the development of the effective tax burden in the EU-25 Member States, it is important to further include the development of the taxation of shareholders. Within the framework of the European Tax Analyzer, the ownership structure is composed of ten resident shareholders (natural persons) with shareholdings between 5\% and 51\%. Apart from a dividend in line with the size of their stake, shareholders receive interest income at 3.5\% from a loan granted to the corporation. Again, the amount of interest received depends on the shareholders' respective participation. At the end of the last simulation period, shareholders receive an additional dividend from the distribution of built-up reserves after accounting for taxes on hidden reserves or losses. To account for the effects of tax progression, each shareholder is assumed to receive a virtual income at EUR 50,000. At the end of each period, the amount of taxes due on the virtual income is again subtracted from the overall tax burden. Similar to the calculation of the effective tax burden at corporate level, the effective tax burden is derived as the difference between pre- and post-tax assets. In the following, we will consider the effective tax burden at corporate level and at the overall level, i.e. at both corporate and shareholder level.

The rates of price increase are derived from Eurostat and the Statistical Office of Germany. The numbers displayed are the average of the monthly or quarterly values of 2012, see also Spengel et al. (2015), Annex 1, p. 65.

64 Interest rates are derived from the European Central Bank's MFI interest rate statistics. The numbers displayed are the average monthly values of 2012 with short-term referring to a period of up to one year and long-term referring to a period of longer than one year. See also Spengel et al. (2015), Annex 1, p. 65. 


\subsection{Results of the Calculations and Discussion}

\subsubsection{Average Effective Tax Burden for the EU-15/EU-10 Member States}

To facilitate the understanding and to derive some general conclusions regarding the development in the European Union, Figure 6 illustrates the development of the effective tax burden as the unweighted average across the respective subgroup (EU-15/EU-10) as well as with respect to the minimum and maximum effective tax burdens at both corporate and overall (corporate and shareholder) level. The effective tax burden is the total tax payment in million Euro for the ten simulation periods. For each of the calculations, the identical average model corporation has been used.

Figure 6: Average, Minimum and Maximum Effective Tax Burden for the EU-15 and EU-10 between 1998 and 2015 (in Million Euro)
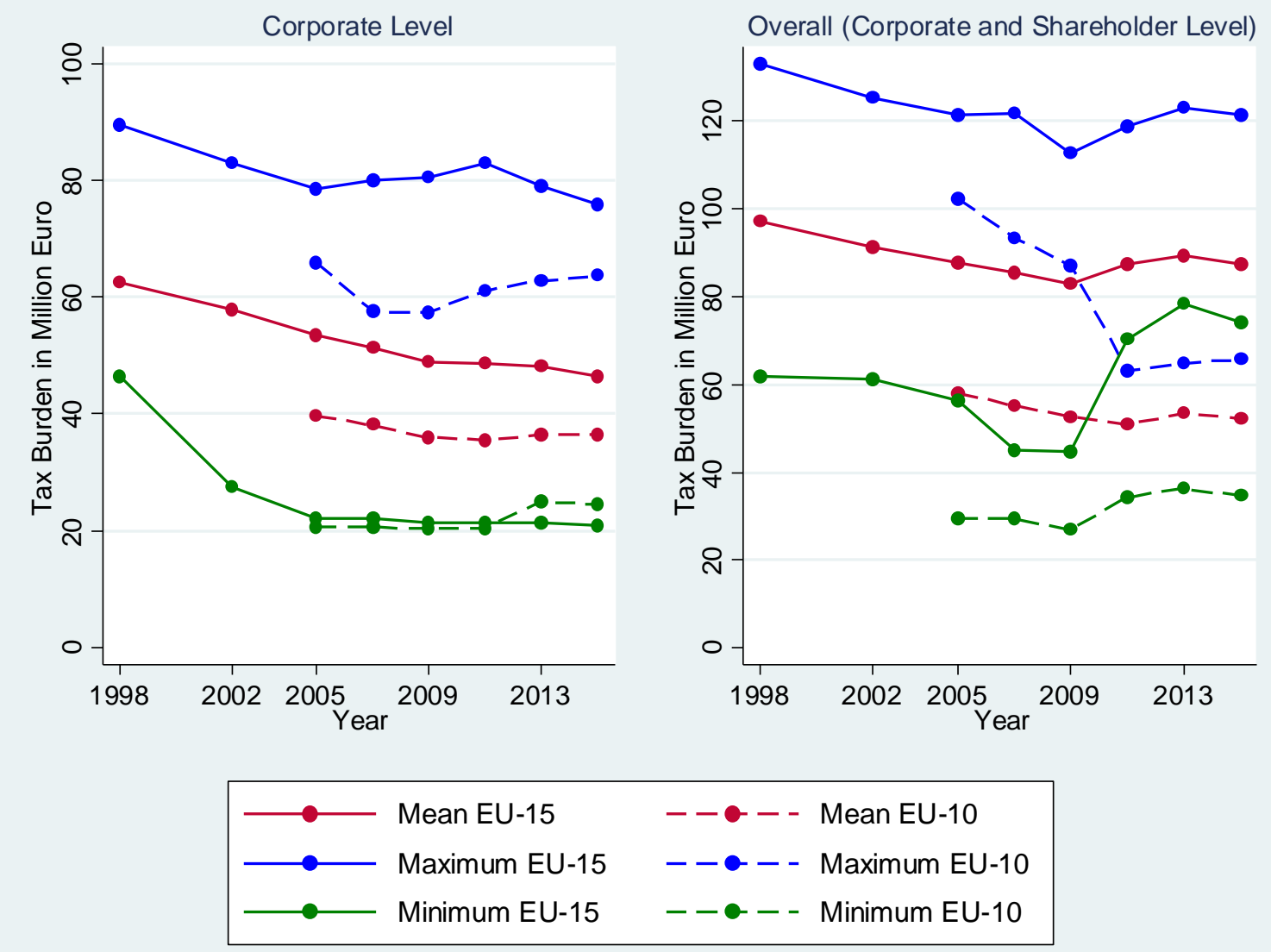

Especially for the EU-15 Member States, the average effective corporate tax burden is considerably declining from EUR 62.37 million in 1998 to EUR 46.56 million in 2015. The overall reduction of the average effective corporate tax burden between 1998 and 2015 thus amounts to $25.3 \%$ which is lower than the decrease in average effective corporate income tax 
rates at $29.3 \%{ }^{65}$ Thus, it can be concluded that although especially from 2007 through 2015 , many EU-15 Member States employ tax base broadening measures (see section 2.3.), these measures do not even nearly compensate for the tax rate reductions based on the specific model enterprise used for our calculations. For the EU-10, the average effective corporate tax burden only slightly decreases from EUR 39.64 million in 2005 to EUR 36.41 million in 2015, however it even slightly increases since 2011. The structural differences between the two subgroups of the EU-15 and EU-10 that have already been identified in the qualitative analysis are clearly highlighted by both a lower average as well as a lower maximum effective tax burden for the EU-10.

Among the EU-15, the Member States with the highest and lowest effective tax burden remain very constant from 1998 through 2015: Throughout the whole period, the highest effective corporate tax burden is found in France. In the context of the findings of the qualitative analysis, this outcome is especially interesting for the first partial period from 1998 to 2007 since the corporate income tax rate was reduced and most base narrowing measures were implemented in France (see Figure 4 above). The lowest effective tax burden can be found in Ireland after a sharp reduction of the general corporate income tax rate in 2002. Before, the effective tax burden was lowest in Sweden. This switch is only caused by changes to the corporate income tax rate in Ireland since there is neither base broadening nor base narrowing in Ireland or Sweden. The lowest effective corporate tax burden among the EU-10 Member States is always found in Cyprus. The Member State with the highest effective tax burden changes between Slovenia (2005), Malta (2007-2009) and Hungary (2011-2015).

In case the taxation at shareholder level is also included into the considerations, differences in the development of the effective tax burdens of the EU-15 and EU-10 Member States become even more apparent: Since 2011, the minimum effective tax burden among the EU-15 is higher than the maximum effective tax burden among the EU-10 Member States. Among the EU-10 Member States, the maximum overall effective tax burden (Hungary) considerably decreases in 2011 due to the reduction of the dividend tax rate from $25 \%$ to $16 \%{ }^{66}$ Apart from lower corporate income tax rates, the lower overall effective tax burden among the EU-10 also stems from the lower taxation of dividend and other capital income at shareholder level: In Estonia,

66 The tax rate of $16 \%$ is further reduced depending on the holding period such that from the sixth year onwards, dividends are not taxed at all anymore. 
Latvia (until 2011) and the Slovak Republic, dividend income remains untaxed in the hands of the shareholder.

A comparison of the development of effective tax burdens at the corporate and the overall level provides further important insights. Whereas the effective corporate tax burden predominantly decreases, the overall effective tax burden increases in the EU-15 from 2011 on and in the EU-10 Member States from 2013 on. One reason for this contrary development of corporate and overall effective tax burdens is - as concluded in section 4 - the enhanced taxation of dividends at shareholder level.

\subsubsection{Country-Specific Developments in Effective Tax Burdens}

By considering unweighted average effective tax burdens of the subgroups, it is not possible to gain deeper insights on potential heterogeneous developments across Member States. However, a thorough understanding of the development of the tax structures in single Member States is especially relevant when evaluating whether and to which extent effective tax burdens have assimilated across Member States over time. Therefore, the effective tax burden at corporate level is shown for every Member State and every year in Table 5. 
Table 5: Country-Specific Development of the Effective Tax Burden between 1998 and 2015 (Corporate Level, in Million Euro)

\begin{tabular}{|c|c|c|c|c|c|c|c|c|}
\hline & 1998 & 2002 & 2005 & 2007 & 2009 & 2011 & 2013 & 2015 \\
\hline AT & 64.79 & 64.20 & 50.95 & $\underline{50.95}$ & 50.99 & 51.08 & 51.09 & 51.09 \\
\hline $\mathrm{BE}$ & 66.56 & 66.56 & 57.17 & 54.28 & 54.39 & 54.39 & 54.15 & $\underline{54.15}$ \\
\hline $\mathrm{DE}$ & 78.35 & 65.52 & 65.78 & 65.62 & $\underline{52.39}$ & 52.84 & 53.38 & 53.58 \\
\hline DK & 57.93 & 51.75 & 48.59 & 43.85 & 43.86 & 43.86 & 43.86 & $\underline{41.48}$ \\
\hline EL & 57.82 & 57.69 & 52.75 & 41.42 & 41.43 & $\underline{33.34}$ & 43.54 & 49.54 \\
\hline ES & 65.65 & 65.65 & 65.65 & 61.91 & 58.13 & 58.13 & 58.13 & $\underline{55.23}$ \\
\hline FI & 46.55 & 48.60 & 43.79 & 43.79 & 43.71 & 44.15 & 41.37 & $\underline{34.49}$ \\
\hline FR & 89.33 & 82.87 & 78.53 & 80.04 & 80.54 & 82.99 & 78.96 & 75.91 \\
\hline IE & 53.18 & 27.47 & 22.20 & 22.04 & 21.53 & 21.50 & 21.48 & $\underline{21.01}$ \\
\hline IT & 72.79 & 73.60 & 67.98 & 68.86 & 57.38 & 57.31 & 55.99 & $\underline{52.27}$ \\
\hline LU & 60.85 & 51.47 & 51.47 & 52.99 & $\underline{49.68}$ & 50.12 & 50.79 & 50.79 \\
\hline NL & 57.54 & 57.18 & 52.16 & 42.41 & 42.00 & 41.49 & 41.52 & $\underline{41.48}$ \\
\hline PT & 61.04 & 55.06 & 45.52 & 43.91 & 43.93 & 47.34 & 49.83 & $\underline{43.40}$ \\
\hline SE & 46.54 & 46.54 & 46.54 & 46.54 & 43.80 & 43.80 & 36.87 & $\underline{36.87}$ \\
\hline UK & 56.70 & 54.82 & 52.24 & 52.31 & 49.52 & 45.97 & 41.58 & $\underline{36.94}$ \\
\hline$\varnothing$ EU-15 & 62.37 & 57.93 & 53.42 & 51.40 & 48.89 & 48.55 & 48.17 & 46.55 \\
\hline $\mathrm{CY}$ & - & - & 20.61 & 20.61 & 20.50 & 20.50 & 24.96 & 24.60 \\
\hline $\mathrm{CZ}$ & - & - & 42.74 & 39.54 & 33.04 & 31.55 & 31.54 & $\underline{31.52}$ \\
\hline $\mathrm{EE}$ & - & - & 39.40 & 36.18 & 34.57 & 34.57 & 34.57 & $\underline{32.96}$ \\
\hline $\mathrm{HU}$ & - & - & $\underline{52.25}$ & 56.34 & 56.18 & 61.10 & 62.82 & 63.67 \\
\hline LT & - & - & 26.46 & 31.28 & 33.70 & $\underline{25.93}$ & 28.23 & 28.23 \\
\hline LV & - & - & 27.37 & 27.37 & $\underline{24.93}$ & 25.84 & 25.84 & 27.29 \\
\hline MT & - & - & 57.50 & 57.50 & 57.45 & 57.45 & 57.45 & $\underline{57.45}$ \\
\hline PL & - & - & $\underline{32.65}$ & 32.82 & 32.77 & 32.74 & 32.88 & 32.90 \\
\hline SI & - & - & 66.00 & 46.76 & 34.59 & 32.95 & 28.05 & $\underline{28.05}$ \\
\hline SK & - & - & $\underline{31.30}$ & 32.31 & 32.45 & 32.45 & 39.01 & 37.46 \\
\hline$\varnothing \mathbf{E U - 1 0}$ & - & - & 39.63 & 38.07 & 36.02 & 35.51 & 36.53 & 36.41 \\
\hline$\varnothing$ EU-25 & - & - & 47.90 & 46.07 & 43.74 & 43.34 & 43.52 & 42.50 \\
\hline
\end{tabular}

The highlighted values represent the lowest country-specific effective tax burden during the time period considered.

From Table 5, it is evident that the effective corporate tax burden has considerably decreased since 1998 across all EU-15 Member States. In nearly all Member States, the highest effective corporate tax burden can be found in 1998. Exceptions are Finland and Italy where the tax burden is highest in 2002. In the opposite way, the effective corporate tax burden is lowest in the vast majority of the EU-15 Member States in the last year of our observation period (2015). Exceptions are Austria, Germany, Greece and Luxembourg. Altogether, effective corporate tax burdens still seem to decrease despite increasing fiscal needs as a result of the economic and sovereign debt crisis. Also, in countries where the trend of tax rate cut cum tax base broadening has been identified, decreases in effective corporate tax rates seem to overcompensate base broadening policies at least for the large EU-28 average model corporation considered. 
Although the effective tax burden decreases in all Member States, remarkable differences in the tax burdens among the Member States persist.

Except for Hungary and Malta, the effective tax burden is much lower among the EU-10 Member States. In general, the spread of tax burdens is lower compared to the EU-15 and effective tax levels in all other Member States are close to the lowest EU-15 level in Ireland. In contrast to the EU-15, there is no general decline in effective corporate tax burdens and the effective tax burden is lowest in only three Member States in 2015 (Estonia, Czech Republic and Slovenia). The considerable decrease in the effective corporate tax burden in the Slovak Republic mainly results from the abolition of the payroll tax in 2009 and the reduction of the corporate income tax rate from $25 \%$ in 2005 to $17 \%$ in 2015 . In contrast, a steady increase in the effective corporate tax burden is observed in Hungary which stems from a reduced deductibility of local taxes from the corporate income tax base as well as an increase in the corporate income tax rate from $16 \%$ (2005) to $19 \%$ (2015).

Given the valuable insights from the analysis of effective corporate tax burdens at the corporate level, in the following, we conduct a similar analysis for the overall effective tax burden (corporate and shareholder level) which is illustrated in Table 6. 
Table 6: Country-Specific Development of the Effective Tax Burden between 1998 and 2015 (Corporate and Shareholder Level, in Million Euro)

\begin{tabular}{|c|c|c|c|c|c|c|c|c|}
\hline & 1998 & 2002 & 2005 & 2007 & 2009 & 2011 & 2013 & 2015 \\
\hline $\mathrm{AT}$ & 94.44 & 94.00 & 84.07 & 84.07 & $\underline{83.74}$ & 83.80 & 84.10 & 84.10 \\
\hline $\mathrm{BE}$ & 92.82 & 92.82 & 85.78 & $\underline{83.61}$ & 83.71 & 83.69 & 84.22 & 84.27 \\
\hline $\mathrm{DE}$ & 113.89 & 97.34 & 93.65 & 94.80 & $\underline{87.22}$ & 88.02 & 88.41 & 88.55 \\
\hline DK & 106.24 & 106.06 & 104.26 & 101.39 & 104.03 & 99.13 & 99.02 & $\underline{97.47}$ \\
\hline EL & 61.83 & 61.28 & 56.35 & 44.91 & $\underline{44.85}$ & 70.42 & 82.96 & 74.21 \\
\hline ES & 105.37 & 105.55 & 101.13 & 92.80 & $\underline{81.26}$ & 100.01 & 106.56 & 100.98 \\
\hline FI & 88.83 & 86.70 & 87.60 & 83.17 & 83.07 & 83.41 & 85.05 & $\underline{81.69}$ \\
\hline FR & 133.24 & 125.25 & 121.40 & 121.86 & 112.64 & 119.00 & 123.20 & 121.44 \\
\hline IE & 104.02 & 89.14 & 86.08 & $\underline{85.99}$ & 91.55 & 94.86 & 99.33 & 99.11 \\
\hline IT & 93.45 & 95.05 & 90.61 & 91.64 & $\underline{80.21}$ & 80.74 & 83.68 & 84.16 \\
\hline LU & 89.84 & 79.07 & 79.07 & 78.09 & $\underline{75.33}$ & 77.63 & 78.97 & 79.60 \\
\hline NL & 113.09 & 87.64 & 83.85 & $\underline{77.98}$ & 78.91 & 78.52 & 78.54 & 78.47 \\
\hline PT & 86.75 & 73.52 & $\underline{66.87}$ & 71.65 & 71.49 & 74.84 & 84.91 & 80.29 \\
\hline SE & 89.95 & 89.86 & 90.10 & 85.10 & 83.19 & 83.19 & 78.33 & 78.33 \\
\hline UK & 81.70 & 86.53 & 84.60 & 84.95 & 82.20 & 92.97 & 83.51 & $\underline{80.21}$ \\
\hline$\varnothing$ EU-15 & 97.03 & 91.32 & 87.69 & 85.47 & 82.89 & 87.35 & 89.39 & 87.52 \\
\hline $\mathrm{CY}$ & - & - & 43.33 & 43.33 & 43.23 & 46.63 & 56.00 & 51.49 \\
\hline $\mathrm{CZ}$ & - & - & 64.04 & 61.28 & 54.19 & 53.13 & 53.11 & $\underline{53.10}$ \\
\hline $\mathrm{EE}$ & - & - & 41.40 & 38.01 & 36.32 & 36.32 & 36.32 & $\underline{34.63}$ \\
\hline $\mathrm{HU}$ & - & - & 90.24 & 93.39 & 87.25 & $\underline{63.15}$ & 64.88 & 65.73 \\
\hline LT & - & - & $\underline{47.30}$ & 51.40 & 60.05 & 53.83 & 55.68 & 50.31 \\
\hline LV & - & - & 29.46 & 29.46 & $\underline{26.84}$ & 40.80 & 40.80 & 42.10 \\
\hline MT & - & - & 69.18 & 69.18 & 60.62 & 60.62 & 60.61 & $\underline{60.59}$ \\
\hline PL & - & - & $\underline{59.75}$ & 59.89 & 59.85 & 59.83 & 59.94 & 59.96 \\
\hline SI & - & - & 102.48 & 71.96 & 62.71 & $\underline{61.40}$ & 64.81 & 64.81 \\
\hline SK & - & - & $\underline{33.18}$ & 34.24 & 34.37 & 34.37 & 41.43 & 39.88 \\
\hline$\varnothing \mathbf{E U - 1 0}$ & - & - & 58.04 & 55.21 & 52.54 & 51.01 & 53.36 & $5 ., 26$ \\
\hline$\varnothing$ EU-25 & - & - & 75.83 & 73.37 & 70.75 & 72.81 & 74.97 & 73.42 \\
\hline
\end{tabular}

The highlighted values represent the lowest country-specific effective tax burden during the time period considered.

Except for Greece, the overall effective tax burden is lower in 2015 than in 1998 in all EU-15 Member States. It is striking, however, that in contrast to the uniform development at corporate level, the effective tax burden is lowest in only four Member States in 2015 (Denmark, Finland, Sweden, United Kingdom). Although the overall differences are in part very small, the overall effective tax burden is lowest in nearly half of the Member States in 2009 (Austria, France, Germany, Greece, Italy, Luxembourg and Spain). In the qualitative analysis, it has been found that an increased taxation of dividends has especially been used since 2007 to compensate for further tax reliefs at the corporate level. As evident from the increasing effective overall tax burden, the higher taxation of dividends even overcompensates decreases in the effective 
corporate tax burden for the considered model corporation. In Ireland, the overall effective tax burden amounts to EUR 99.11 million in 2015 and is thus almost equal to the initial level of EUR 104.02 million in 1998. This results in particular from the introduction and continuous increase of a progressive surcharge within the personal income tax in 2011 with a top rate of $11 \%$ in 2015.

Additionally, the developments in the overall effective tax burden in the EU-15 and EU-10 Member States shown in Table 6 confirm the clear distinction between the two subgroups that has already been identified in the analysis of the average effective tax burden. As for the corporate level, there is no uniform development among the EU-10 Member States: The overall effective tax burden is lowest in three Member States in 2005 (Lithuania, Poland, Slovak Republic) and 2015 (Estonia, Malta, Czech Republic), respectively. However, the changes are rather small in several countries and mainly attributable to changes in corporate taxation.

\subsubsection{Sensitivity Analysis}

So far, we have considered the development of both the corporate and overall effective tax burden based on the calculations for a large EU-28 average model corporation with certain economic parameters. To generalise the above conclusions, a sensitivity analysis is conducted where single economic figures of the model corporation are varied. In the following, we will vary the profitability, asset intensity, equity ratio and labour intensity, respectively. ${ }^{67}$

By increasing or decreasing sales within the simulation, it is possible to vary the profitability. Higher sales should lead to higher taxable profits and thus to higher effective tax burdens. For the asset intensity, we will increase the percentage of fixed assets while the amount of total assets is held constant. In consequence, a high asset intensity should lead to higher depreciable amounts per year which is assumed to lead to a lower effective tax burden. We will further adjust long-term liabilities to vary the equity ratio. In general, higher interest deductions should lead to lower taxable profits and thus result in a lower effective tax burden. However, in this regard, interest deduction limitation rules could countervail this effect. The labour intensity is based on the share of labour costs with respect to sales. For the sensitivity analysis, we will thus increase or decrease salaries. Higher labour costs are assumed to result in lower profits and a lower effective tax burden. Still, the effects of payroll taxes have to be considered in several

67 A similar sensitivity analysis has also been conducted in Spengel et al. (2008), pp. 62-71 as well as Spengel et al. (2015), Annex 1, pp. 68-70. 
countries. In Table 7, the initial values for the different parameters of the average model corporation as well as the considered increases or decreases for single ratios are shown.

Table 7: Variation of Initial Values for Different Sensitivity Analyses

\begin{tabular}{|c|ccc|}
\cline { 2 - 4 } \multicolumn{1}{c|}{} & $\begin{array}{c}\text { Reduction by } \\
\text {-30\%/-15\% }\end{array}$ & Initial value & $\begin{array}{c}\text { Increase by } \\
+\mathbf{3 0} \% /+\mathbf{1 5} \%\end{array}$ \\
\hline Profitability & $3.47 \%$ & $4.95 \%$ & $6.44 \%$ \\
Asset intensity & $20.34 \%$ & $23.93 \%$ & $27.52 \%$ \\
Equity ratio & $29.80 \%$ & $42.57 \%$ & $55.34 \%$ \\
Labour intensity & $7.32 \%$ & $10.46 \%$ & $13.60 \%$ \\
\hline
\end{tabular}

The profitability, equity ratio and labour intensity are varied by $-30 \% /+30 \%$. The variation in terms of the asset intensity is $-15 \% /+15 \%$.

For the sensitivity analysis, the resulting effective tax burden is calculated for every Member State in each of the considered years for each sensitivity model. To reduce complexity, only the average effective tax burdens at corporate level are shown for the EU-15 and EU-10 in Figure 7.

Figure 7: Sensitivity Analysis for the Large EU-28 Average Model Corporation (Corporate Level)
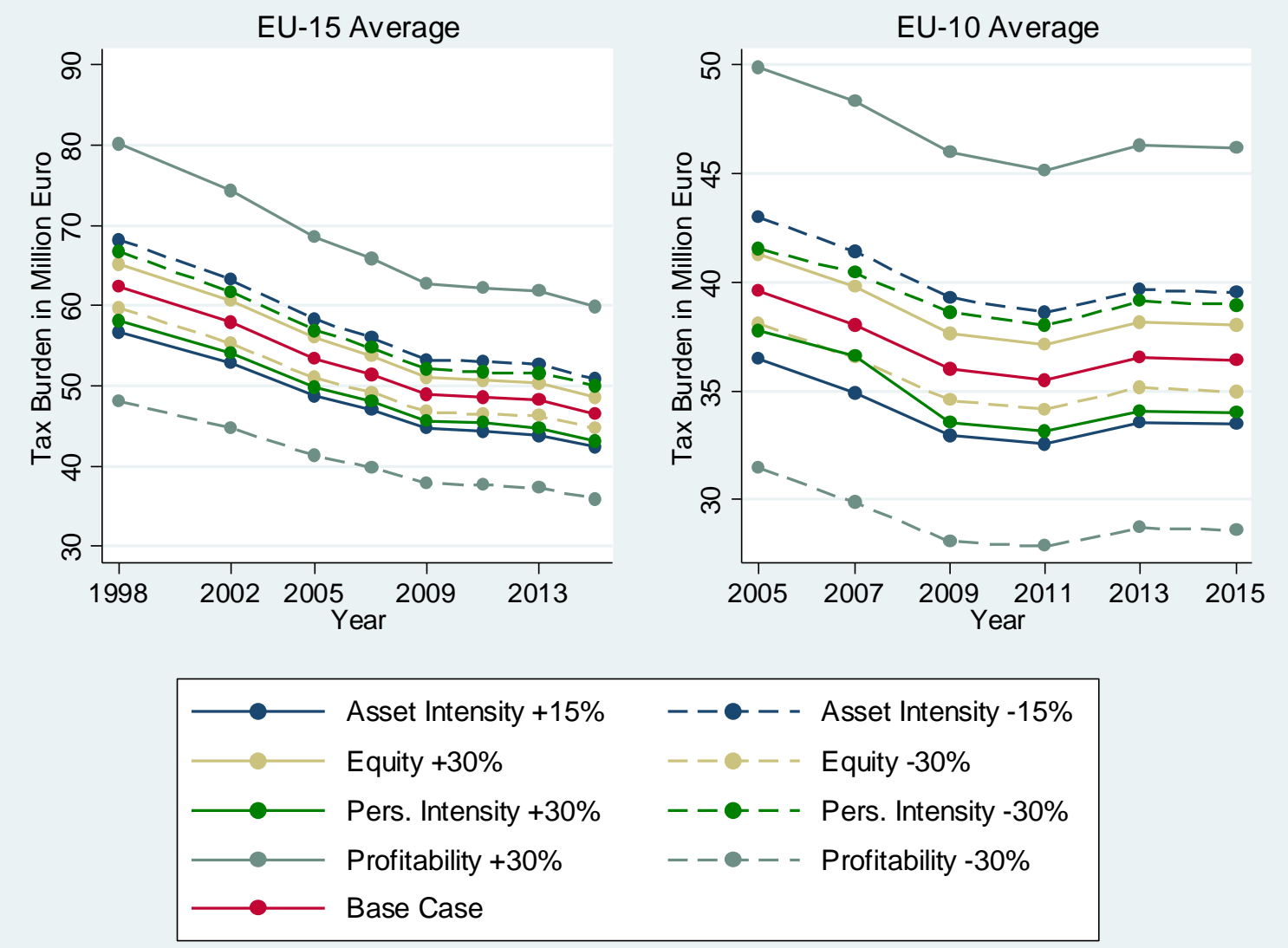
For both subgroups, the sensitivity analysis confirms the general conclusions of the baseline analysis at the corporate and overall (corporate and shareholder) level. With regard to the corporate level, the effective average tax burden for the EU-15 strongly declines, whereas the decline is less pronounced among the EU-10 Member States and the effective tax burden has even slightly increased since 2011 for all model firms. As expected, a lower profitability and equity ratio as well as a higher capital and labour intensity result in a lower effective tax burden. The comparatively high variation in the effective tax burdens for model corporations with different levels of profitability illustrates the relative high impact of the profitability on the level of the effective tax burden. For the variation of the equity ratio and the labour intensity, interest deduction limitation rules and payroll taxes may partially offset expected lower effective tax burdens for lower equity ratios and a higher labour intensity. An example is the abolition of the payroll tax in Slovenia in 2009 which has a much larger impact on the effective average tax burden in case of a high labour intensity than in the baseline scenario. Variations to the equity ratio show only little effect. This may mainly be due to the low interest rates that are applicable within the framework of the European Tax Analyzer.

The conclusions for the overall level are also the same if the results for the sensitivity analysis are compared to the initial results and conclusions. The development over time is shown in Figure 8. Again, it turns out for all sensitivity models that the overall effective tax burden is increasing since 2011 (EU-15) or 2013 (EU-10), respectively. Similar to the corporate level, the variation of the profitability has a higher impact on the final corporate tax burden. 
Figure 8: Sensitivity Analysis for the Large EU-28 Average Model Corporation (Corporate and Shareholder Level)

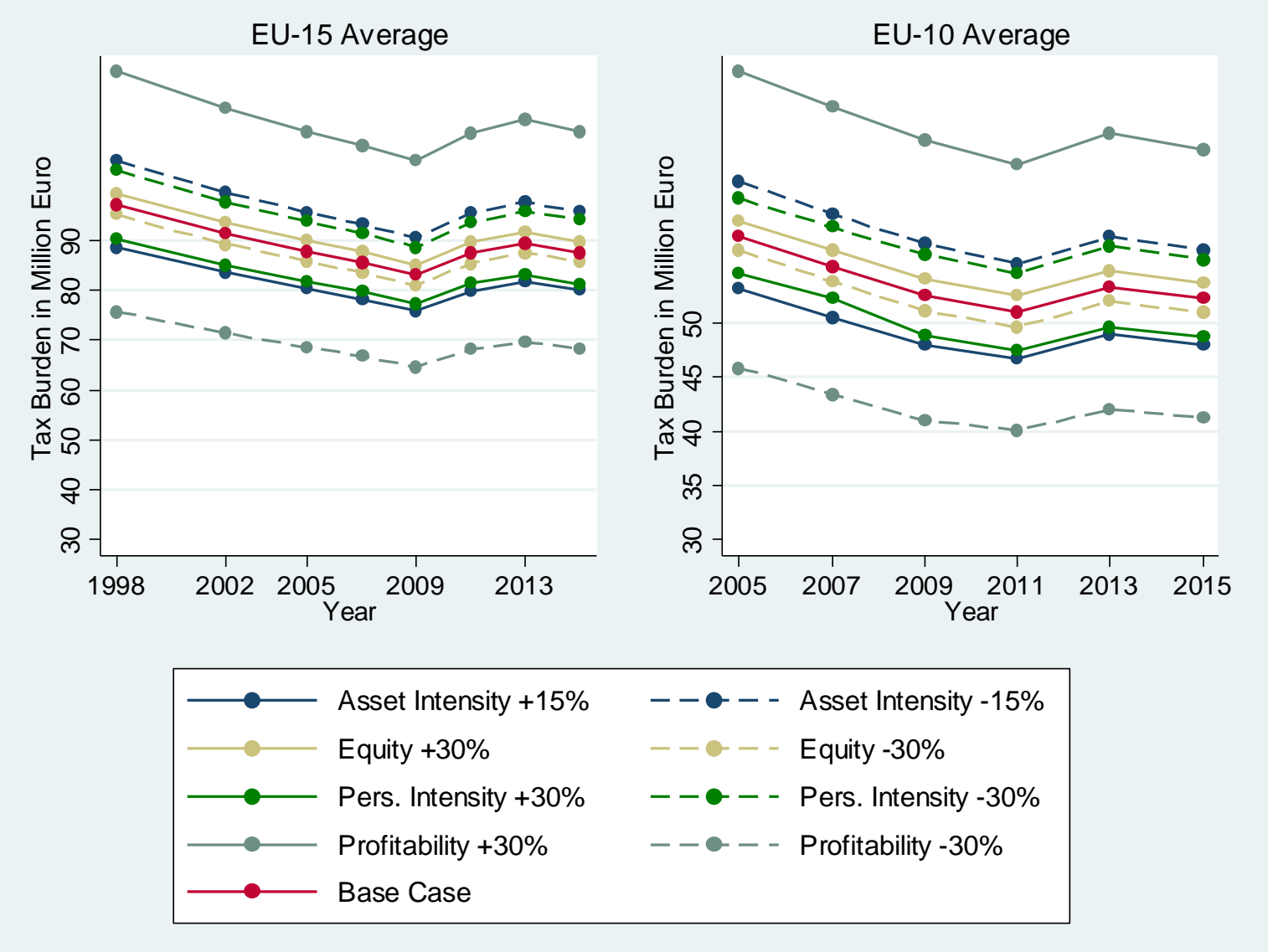

\section{Conclusion}

Our comprehensive analysis of the development of tax structures among the EU-25 Member States confirms the presence of the often-cited trend of tax rate cut cum tax base broadening for the period from 1998 through 2015. It can in particular be identified among the EU-15 Member States and especially since 2007. Several Member States, however, have increased corporate income tax rates and implemented reforms that lead to broader tax bases to alleviate the effects of the financial and sovereign debt crisis. In terms of tax base broadening, we find that depreciation rules are less relevant whereas other provisions such as interest deduction limitation rules and limitations to loss utilization have become more important drivers of tax base broadening. Furthermore, especially in recent years, increases in the personal income tax rate on dividend income seem to be an additional compensatory measure for the effects of the observed decrease in corporate income tax rates. 
The related quantitative analysis of the development of effective tax burdens within the framework of the European Tax Analyzer illustrates that the effective tax burden has considerably declined since 1998. Although differences in country-specific effective tax burdens persist especially among the EU-15 Member States, the downward trend in effective tax burdens indicates that tax competition is still - even after the financial and sovereign debt crisis - of current relevance in the EU. In contrast, when including shareholder taxation into the considerations, the overall effective burden appears to increase in recent years in both subgroups. This observation confirms one of the key findings of the qualitative analysis where it was held that an enhanced taxation of dividends at the shareholder level is likely to compensate potential revenue losses that result from lower corporate income tax rates.

In summary, the overall situation in the EU is mainly determined by an intense tax competition among the Member States. However, more restrictive loss provisions and interest deduction limitation rules as a means to finance corporate tax rate cuts can have severe consequences for the effective tax burden of corporations. The sovereign debt crisis has to be seen as a special case. In the near future, it can be expected that tax competition will continue. Member States such as Denmark in 2016 and Italy in 2017 have further reduced their corporate income tax rates. Moreover, the United Kingdom and the United States have announced major tax reforms which may also contribute to a fiercer tax competition within the EU. 


\section{Appendix 1 - Description and Specification of Base Broadening Parameters}

\section{Depreciation $^{68}$}

+1 Member State switches from any depreciation method to straight line depreciation for a certain asset

-1 Member State no longer stipulates straight line depreciation

Valuation of inventories

+1 Member State refrains from the LIFO method in the valuation of inventories

$-1 \quad$ Inventories need to be valued according to the LIFO method

Interest deduction limitation rules

+1 Interest deduction limitation rules are introduced or tightened (switch from fixed ratio approach to earnings stripping rule)

-1 Abolition of interest deduction limitation rules

Notional interest deduction

+1 Abolition of notional interest deduction

$-1 \quad$ Introduction of a notional interest deduction

Treatment of losses ${ }^{69}$

\section{Loss carry forward}

+1 Introduction of limitation to loss carry forward amount (absolute and relative); restriction of loss carry forward with regard to time (if previously unlimited in time)

-1 Abolition of limits to loss carry forward amount; extension to a loss carry forward unlimited in time

68 In case changes to the depreciation method occur for several assets, the overall base broadening value for depreciation may nevertheless not be higher (lower) than $+1(-1)$.

69 Since the tax base indicator for the treatment of losses is measured along various dimensions, there could be several changes during the relevant observation period. The resulting measures are added up. In consequence, it could be the case that base broadening and base narrowing provisions cancel out and result in a base broadening value of 0 . 
Loss carry back

$+1 \quad$ Carry back period limited

-1 Carry back period extended

\section{Other taxes}

+1 Restriction or refusal of deductibility of other corporate (profit) taxes

-1 Deductibility of other corporate (profit) taxes granted or extended 
Appendix 2 - Exemplary Computation of Effective Personal Income Tax Rates in Italy in 1998 and 2015

\begin{tabular}{|r|c|c|}
\hline & 1998 & 2015 \\
\hline Type of corporate tax system & Partial imputation & Shareholder relief \\
\hline Dividend tax credit & $58.73 \%$ & - \\
\hline $\begin{array}{r}\text { Partial exemption of } \\
\text { dividend }\end{array}$ & - & $40.28 \%$ \\
\hline $\begin{array}{r}\text { Highest marginal personal } \\
\text { income tax rate (dividends) }\end{array}$ & $46.00 \%$ & $3 \% .03 \%$ \\
\hline $\begin{array}{r}\text { Surcharge } \\
\text { (solidarity contribution) }\end{array}$ & - & (if income $>$ EUR 300,000) \\
\hline
\end{tabular}

In 1998, a partial imputation system was in place in Italy. Dividends carried an imputation credit at $58.73 \%$ of the net dividend received which effectively increased shareholders' taxable income. ${ }^{70}$ The gross-up could, however, then again be credited against the shareholders' tax on the dividend. The highest marginal personal income tax rate on dividends was at $46 \%$. As follows from the below calculation, the effective personal income tax rate on dividends thus amounts to $14.29 \%$ :

Dividend

\begin{tabular}{lcr}
+ Imputation tax credit (gross-up) & $58.73 \% * 100$ & 58.73 \\
\hline$=$ Taxable income & & 158.73 \\
$*$ Personal income tax rate & $46.00 \%$ & 73.02 \\
\hline$=$ Personal income tax & & 58.73 \\
- Dividend tax credit & $58.73 \% * 100$ & \\
\hline \hline
\end{tabular}

= Tax due at shareholder level

In 2015, dividends were partially exempt at 50.28\%. The highest marginal personal income tax rate amounted to $45.03 \%$. In addition, the progressive rate was increased by a $3 \%$ solidarity surcharge in case the shareholder's overall taxable income exceeded EUR 300,000. Following

70 The amount of the imputation tax credit at $58.73 \%$ rests on the assumption that a dividend received from a domestic corporation had already been taxed at the corporate income tax rate of $37 \%$. In case a corporate shareholder received that dividend, a tax credit at $58.73 \%$ of the received dividend effectively resulted in a full imputation. 
from the below calculations, the effective personal income tax rate on dividends amounts to $23.06 \%$ :

Dividend

- Partial exemption

$50.28 \% * 100$ 50.28

$=$ Taxable income 49.72

* Personal income tax rate $45.03 \%$

$=$ Personal income tax 22.39

+ Solidarity surcharge

$3 \% * 22.39$ 0.67

= Tax due at shareholder level 


\section{References}

Alstadsæter, A./Jacob, M. (2016), Dividend Taxes and Income Shifting, The Scandinavian Journal of Economics 118 (4), pp. 693-717.

Andrae, K. (2015), Grundsteuer und Gewerbesteuer; Update 2014 - Entwicklung der Hebesätze der Gemeinden mit 20.000 und mehr Einwohnern im Jahr 2014 gegenüber 2013. ifst-Schrift 504, Berlin.

Becker, J./Fuest, C. (2011), Optimal tax policy when firms are internationally mobile, International Tax and Public Finance 18 (5), pp. 580-604.

Bellak, C./Leibrecht, M./Damijan, J.P. (2009), Infrastructure Endowment and Corporate Income Taxes as Determinants of Foreign Direct Investment in Central and Eastern European Countries, World Economy 32 (2), pp. 267-290.

Benz, S./Böhmer, J. (2017), Der RegE eines § 4j EStG zur Beschränkung der Abziehbarkeit von Lizenzzahlungen (Lizenzschranke), Der Betrieb 70 (5), pp. 206-211.

Bond, S. (2000), Levelling up or levelling down? Some reflections on the ACE and CBIT proposals, and the future of the corporate tax base, in: Cnossen, S. (ed.), Taxing Capital Income in the European Union: Issues and Options for Reform, Oxford, pp. 161-179.

Bond, S./Xing, J. (2015), Corporate taxation and capital accumulation, Journal of Public Economics 130, pp. 15-31.

Bucovetsky, S./Wilson, J.D. (1991), Tax competition with two tax instruments, Regional Science and Urban Economics 21 (3), pp. 333-350.

Clausing, K.A. (2007), Corporate tax revenues in OECD countries, International Tax and Public Finance 14 (2), pp. 115-133.

Cnossen, S. (2001), Tax Policy in the European Union: A Review of Issues and Options, FinanzArchiv: Public Finance Analysis 58 (4), pp. 466-558.

Commission of the European Communities (1992), Report of the Committee of Independent Experts on Company Taxation, Brussels. 
Crabbé, K. (2013), Are Your Firm's Taxes Set in Warsaw? Spatial Tax Competition in Europe, FinanzArchiv: Public Finance Analysis 69 (3), pp. 317-337.

Davies, R.B./Voget, J. (2008), Tax Competition in an Expanding European Union, Oxford University Centre for Business Taxation Working Paper 08/30, Oxford.

de Mooij, R.A. (2011), The Tax Elasticity of Corporate Debt: A Synthesis of Size and Variations, IMF Working Paper WP/11/95, Washington.

Desai, M.A./Foley, F./Hines, J. (2004), A Multinational Perspective on Capital Structure Choice and Internal Capital Markets, The Journal of Finance 59 (6), pp. 2451-2487.

Devereux, M.P. (2007), Developments in the Taxation of Corporate Profit in the OECD since 1965: Rates, Bases and Revenues, Oxford University Centre for Business Taxation WP 07/04, Oxford.

Devereux, M.P. (2008), Business taxation in a globalized world, Oxford Review of Economic Policy 24 (4), pp. 625-638.

Devereux, M.P./Freeman, H. (1991), A General Neutral Profits Tax, Fiscal Studies 12 (3), pp. $1-15$.

Devereux, M.P./Griffith, R. (2003), Evaluating Tax Policy for Location Decisions, International Tax and Public Finance 10 (2), pp. 107-126.

Devereux, M.P./Griffith, R./Klemm, A. (2002), Corporate Income Tax Reforms and International Tax Competition, Economic Policy 17 (35), pp. 449-495.

Devereux, M.P./Loretz, S. (2013), What do we know about corporate tax competition?, National Tax Journal 66 (3), pp. 745-773.

Edmark, K./Gordon, R.H. (2013), The choice of organizational form by closely-held firms in Sweden, Industrial and Corporate Change 22 (1), pp. 219-243.

Egger, P./Raff, H. (2015), Tax rate and tax base competition for foreign direct investment, International Tax and Public Finance 22 (5), pp. 777-810.

Endres, D./Oestreicher, A./Scheffler, W./Spengel, C. (2007), The Determination of Corporate Taxable Income in the EU Member States, Alphen aan den Rijn. 
Endres, D./Spengel, C. (2015), International Company Taxation and Tax Planning, Alphen aan den Rijn.

Endres, D./Spengel, C. (2016), Internationale Unternehmensbesteuerung: Deutsche Investitionen im Ausland, Ausländische Investitionen im Inland, 8th edition, Munich.

European Commission (2015), A Fair and Efficient Corporate Tax System in the European Union: 5 Key Areas for Action (COM(2015) 302 final), Brussels.

European Commission (2016a), Proposal for a Council Directive on a Common Corporate Tax Base, COM(2016) 685 final, Strasbourg.

European Commission (2016b), State aid: Ireland gave illegal tax benefits to Apple worth up to $€ 13$ billion (Press release IP/16/2923), Brussels.

Feld, L.P./Heckemeyer, J.H. (2011), FDI and Taxation: A Meta-Study, Journal of Economic Surveys 25 (2), pp. 233-272.

Feld, L.P./Heckemeyer, J.H./Overesch, M. (2013), Capital structure choice and company taxation: A meta-study, Journal of Banking \& Finance 37 (8), pp. 2850-2866.

Fuest, C./Hemmelgarn, T. (2005), Corporate tax policy, foreign firm ownership and thin capitalization, Regional Science and Urban Economics 35 (5), pp. 508-526.

Genschel, P./Kemmerling, A./Seils, E. (2011), Accelerating Downhill: How the EU Shapes Corporate Tax Competition in the Single Market, Journal of Common Market Studies 49 (3), pp. 585-606.

Griffith, R./Klemm, A. (2004), What has been the Tax Competition Experience of the Last 20 Years?, IFS Working Paper 04/05, London.

Grubert, H./Altshuler, R. (2016), Shifting the Burden of Taxation from the Corporate to the Personal Level and Getting the Corporate Tax Rate Down to 15 Percent, Oxford Business Centre Taxation Working Paper Series WP 16/09, Oxford.

Heidecke, B./Holst, R. (2017a), An Assessment of the Draft Rule Limiting the Deduction of Royalties, International Transfer Pricing Journal 24 (3), pp. 216-220. 
Heidecke, B./Holst, R. (2017b), Begrenzung der Abzugsfähigkeit von Lizenzaufwendungen Zusammenfassung und Problemanzeigen zum Regierungsentwurf vom 25.1.2017, IWB - Internationales Steuer- und Wirtschaftsrecht 2017 (4), pp. 128-137.

Heil, S./Pupeter, A. (2017), Lizenzschranke - Gesetzesentwurf eines neuen § 4j EStG, Betriebs Berater (BB) 72 (14), pp. 795-801.

Jacob, M./Pasedag, A./Wagner, F.W. (2011), Werden niedrige Steuersätze in Osteuropa durch Verzicht auf Verlustverrechnung erkauft?, Perspektiven der Wirtschaftspolitik 12 (1), pp. 72-91.

Kawano, L./Slemrod, J. (2016), How do corporate tax bases change when corporate tax rates change? With implications for the tax rate elasticity of corporate tax revenues, International Tax and Public Finance 23 (3), pp. 401-433.

Loretz, S. (2008), Corporate taxation in the OECD in a wider context, Oxford Review of Economic Policy 24 (4), pp. 639-660.

Mintz, J.M./Weichenrieder, A.J. (2010), The Indirect Side of Direct Investment: Multinational Company Finance and Taxation, Cambridge.

OECD (2013), Action Plan on Base Erosion and Profit Shifting, Paris.

OECD (2015a), Explanatory Statement: OECD/G20 Base Erosion and Profit Shifting Project,

OECD (2015b), Limiting Base Erosion Involving Interest Deductions and Other Financial Payments - Action 4: 2015 Final Report, Paris.

Overesch, M./Wamser, G. (2010), The effects of company taxation in EU accession countries on German FDI, Economics of Transition 18 (3), pp. 429-457.

Owens, J. (1993), Globalisation, Fiscal Studies 14 (3), pp. 21-44.

Panteghini, P./Parisi, M.L./Pighetti, F. (2012), Italy's ACE Tax and its Effect on a Firm's Leverage, CESifo Working Paper No. 3869, Munich.

Ruf, M./Schindler, D. (2015), Debt Shifting and Thin Capitalization Rules - German Experience and Alternative Approaches, Nordic Tax Journal 2015 (1), pp. 17-33. 
Schneider, N./Junior, B. (2017), Die Lizenzschranke - Überblick über den Regierungsentwurf zu § 4j EStG, Deutsches Steuerrecht (DStR) 55 (8), pp. 417-425.

Sørensen, P.B. (1995), Changing Views of the Corporate Income Tax, National Tax Journal 48 (2), pp. 279-284.

Spengel, C. (2008), Tax Science Fiction: Entwicklung der nominalen Steuersätze, internationaler Steuerwettbewerb und Steuerbelastung des Portfolioaktionärs, Rädler, A. J. (Ed.), Tax Science Fiction - Wie sieht unser Steuerrecht in 25 Jahren aus?, Symposium zu Ehren des 75. Geburtstags von Albert J. Rädler, München (), pp. 41-57.

Spengel, C./Bergner, S. (2015), Investitionswirkungen der deutschen Unternehmensbesteuerung im internationalen Vergleich, Report for the German Council of Economic Experts, Mannheim.

Spengel, C./Finke, K./Zinn, B. (2010), Bedeutung der Substanzbesteuerung in Deutschland. Eine qualitative Analyse unter Einbezug von Reformüberlegungen, ZEW Wirtschaftsanalysen Band 96, Baden-Baden.

Spengel, C./Hausemer, P./Bergner, S./Bräutigam, R./Evers, M.T./Plances, S./Streif, F. (2015), SME Taxation in Europe - An Empirical Study of Applied Corporate Income Taxation for SMEs Compared to Large Enterprises. CIP Programme 186/PP/ENT/CIP/12/F/S01C24, Mannheim.

Spengel, C./Heckemeyer, J.H./Streif, F. (2016a), The Effect of Inflation and Interest Rates on Forward-Looking Effective Tax Rates, European Commission Taxation Papers 632016, Luxembourg.

Spengel, C./Meier, I. (2016), Niedrigverzinsung und Unternehmensbesteuerung, Finanz Rundschau Ertragsteuerrecht 98 (11), pp. 496-502.

Spengel, C./Oestreicher, A./Elschner, C./Reister, T./Ernst, C./Grünewald, M./Finke, K./Prassel, J./Cui, L. (2008), Study on the impact of reforms of corporate income taxation systems at the EU level on the size of the tax bases of the EU companies, using the model "European Tax Analyzer". Project for the EU Commission TAXUD/2007/DE/325, Mannheim/Göttingen. 
Spengel, C./Ortmann-Babel, M./Zinn, B./Matenaer, S. (2012), A Common Corporate Tax Base for Europe: An Impact Assessment of the Draft Council Directive on a CC(C)TB, World Tax Journal 4 (3), pp. 185-221.

Spengel, C./Schmidt, F./Heckemeyer, J.H./Nicolay, K. (2016b), Effective Tax Levels Using the Devereux/Griffith Methodology. Project for the EU Commission TAXUD/2013/CC/120. Final Report 2016, Mannheim.

Spengel, C./Zinn, B. (2011), Non-profit Taxation on Corporations in the EU: Lessons from Corporate Tax Reforms in Germany and Tax Implications of the Global Economic Crisis, Intertax 39 (10), pp. 494-520.

Spengel, C./Zöllkau, Y. (2012), Common Corporate Tax Base (CC(C)TB) and Determination of Taxable Income - An International Comparison, Heidelberg.

Trinks, M. (2014), Das Abgabenänderungsgesetz 2014 und die neue "Lizenzschranke", Praxis Internationale Steuerberatung 2014 (4), pp. 99-102.

Zangari, E. (2014), Addressing the Debt Bias: A Comparison between the Belgian and the Italian ACE Systems, European Commission Taxation Papers 44-2014, Luxembourg.

Zodrow, G.R. (2010), Capital Mobility and Capital Tax Competition, National Tax Journal 63 (4), pp. 865-902. 